\title{
U-Pb zircon constraints on the age of the Cretaceous Mata Amarilla Formation, Southern Patagonia, Argentina: its relationship with the evolution of the Austral Basin
}

\author{
Augusto N. Varela1, Daniel G. Poiré1, Thomas Martin², Axel Gerdes ${ }^{3,5}$, Francisco J. Goin ${ }^{4}$, \\ Javier N. Gelfo ${ }^{4}$, Simone Hoffmann², 6
}

\author{
${ }^{1}$ Centro de Investigaciones Geológicas, Universidad Nacional de La Plata-CONICET, Calle 1 No. 644 (B1900FWA) La Plata, Argentina. \\ augustovarela@cig.museo.unlp.edu.ar; poire@cig.museo.unlp.edu.ar \\ ${ }^{2}$ Steinmann-Institut für Geologie, Mineralogie und Paläontologie, Universität Bonn, Nussallee 8, 53115 Bonn, Germany. \\ tmartin@uni-bonn.de; shoffmann@ic.sunysb.edu \\ ${ }^{3}$ Institut für Geowissenschaften, Mineralogie, Universität Frankfurt, Altenhöferallee 1, 60438 Frankfurt am Main, Germany. \\ gerdes@em.uni-frankfurt.de \\ ${ }^{4}$ División Paleontología de Vertebrados, Museo de La Plata, Universidad Nacional de La Plata, Paseo del Bosque s/n (B1900FWA) \\ La Plata, Argentina. \\ fgoin@fcnym.unlp.edu.ar; jgelfo@fcnym.unlp.edu.ar \\ ${ }^{5}$ Department of Earth Sciences, Stellenbosch University, Private Bag X1, Matieland 7602, South Africa. \\ ${ }^{6}$ Department of Anatomical Sciences, Stony Brook University, 11794-8081 New York, U.S.A.
}

\begin{abstract}
Despite the abundant fossil content of the Mata Amarilla Formation (Southern Patagonia, Santa Cruz Province, Argentina), its age has always generated a considerable number of questions and debates. The chronological data provided by invertebrates, dinosaurs, fish, turtles, plesiosaurs and fossil flora are contradictory. In this work, twenty $\mathrm{U}-\mathrm{Pb}$ spot analyses by laser ablation were carried out on the outer parts of the zoned zircon crystals from a tuff layer of the middle section of the Mata Amarilla Formation, yielding a U-Pb concordia age of $96.23 \pm 0.71 \mathrm{Ma}$, which corresponds to the middle Cenomanian. The deposition of the lower section of the Mata Amarilla Formation marks the onset of the foreland stage of the Austral Basin (also known as Magallanes Basin); this transition is characterized by the west-east shift of the depositional systems, which is consistent with the progradation of the Cretaceous fold-and-thrust belt. Thus, the onset of the foreland stage could have occurred between the upper Albian and lower Cenomanian, as the underlying Piedra Clavada Formation is lower Albian in age. On comparing the data obtained with information from the Última Esperanza Province in Chile, it can be suggested that the initiation of the closure of the Rocas Verdes Marginal Basin occurred simultaneously.
\end{abstract}

Keywords: Mata Amarilla Formation, Zircons, Laser ablation, Austral Basin (Rocas Verdes Marginal Basin-Magallanes Basin), Foreland basin, Argentina. 
RESUMEN. Edades U-Pb en circones de la Formación Mata Amarilla (Cretácico), Patagonia Austral, Argentina: su relación con la evolución de la Cuenca Austral. A pesar del abundante contenido fosilífero de la Formación Mata Amarilla (Patagonia Austral, Provincia de Santa Cruz, Argentina), siempre se generaron abundantes dudas y debates acerca de cuál es la edad de esta formación. Los datos cronológicos aportados por los invertebrados, los dinosaurios, peces, tortugas, plesiosaurios y flora fósil son dispares. En el presente trabajo se obtuvo una edad U-Pb concordia por la metodología de ablación láser aplicada a 20 puntos de la parte externa de circones zonados provenientes de un nivel

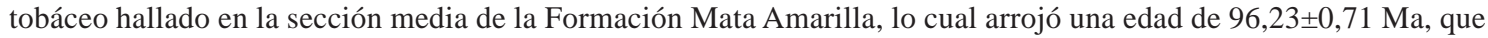
corresponde al Cenomaniano medio. La depositación de la sección inferior de la Formación Mata Amarilla marca el inicio del estadio de antepaís de la Cuenca Austral (también conocida como Cuenca de Magallanes); este pasaje está signado por el cambio oeste-este de los sistemas depositacionales, los cuales se encuentran en concordancia con la progradación de la faja plegada y corrida cretácica. Así, el comienzo del estadio de antepaís quedaría comprendido entre el Albiano superior y el Cenomaniano inferior, debido a que la subyacente Formación Piedra Clavada posee una edad Albiano inferior. Al comparar estos resultados con los datos de la Provincia de Última Esperanza en Chile, se sugiere que el comienzo del cierre de la cuenca marginal de Rocas Verdes se produjo en forma simultánea.

Palabras clave: Formación Mata Amarilla, Circones, Ablación láser, Cuenca Austral (Cuenca Marginal de Rocas Verdes-Cuenca de Magallanes), Cuenca de antepaís, Argentina.

\section{Introduction}

The study area is located in the southwest of the Santa Cruz Province, Argentina, near the locality of Tres Lagos (Fig. 1).

The Mata Amarilla Formation is a key unit in the development of the Austral Basin, as it marks the transition between the thermal subsidence stage and the foreland stage (Varela, 2009, 2011). The exact time of deposition of the Mata Amarilla Formation, however, has always been unclear, and therefore the onset of the compressional phase has also led to dating speculations on the basis of its fossil content. In this respect, the absence of chronological dating has increased the lack of certainty over the stratigraphy of the Austral Basin. In turn, the presence of both continental and littoral fossil specimens has created confusion as to the stratigraphic nomenclature of the unit, since the fossil content was used to refer to lithostratigraphically identical sediments (cf. Goin et al., 2002; Varela, 2011).

In this work, a U-Pb concordia age obtained by laser ablation of primary zircons from a tuff layer of the middle section of the Mata Amarilla Formation is presented. On the basis of such radiometric dating, certain regional considerations regarding the evolution of the Austral Basin (also known as Rocas Verdes Marginal Basin+Magallanes Basin) are introduced.

\section{Geological background}

The Austral Basin, also known towards the south as Rocas Verdes Marginal Basin -when sea-floor spreading occurs- and Magallanes Basin, is located on the southwestern edge of the South American Plate, and it is bounded to the south by the Scotia Plate (Fig. 1). It covers an area of approximately $230,000 \mathrm{~km}^{2}$ which extends over the southernmost end of the Argentine and Chilean territories, and it is surrounded to the east by the Deseado Massif (Macizo del Deseado). With an elongated shape in a north-south direction, bounded to the east by the Río Chico High, which separates it from the Malvinas Basin. Its tectonic western edge is constituted by the Patagonian-Fuegian Andes (Andes Patagónico-Fueguinos, Fig. 1).

This basin consists of a thick sedimentary succession which has a maximum thickness of approximately $8,000 \mathrm{~m}$, with the almost exclusive occurrence of siliciclastic rocks. In the study area, it overlies the Bahía de la Lancha Formation (Biddle et al., 1986; Robbiano et al., 1996; Ramos, 2002; Kraemer et al., 2002; Peroni et al., 2002; Rodríguez and Miller, 2005), and towards the south, the Tierra del Fuego igneous and metamorphic basement complex of Hervé et al. (2010). Carbonate sediments are only present in certain locations within the basin and they are of limited thickness (Peroni et al., 2002).

As shown in figure 1, outcrops of Mesozoic ophiolite complexes are well south of the study area, which indicates that in the study area the basin was not subject to sea-floor spreading. The evolution of the Austral Basin in this sector differs from the evolution of the Rocas Verdes Marginal Basin-Magallanes Basin. The Rocas Verdes Basin is a Late Jurassic- Early Cretaceous backarc basin 


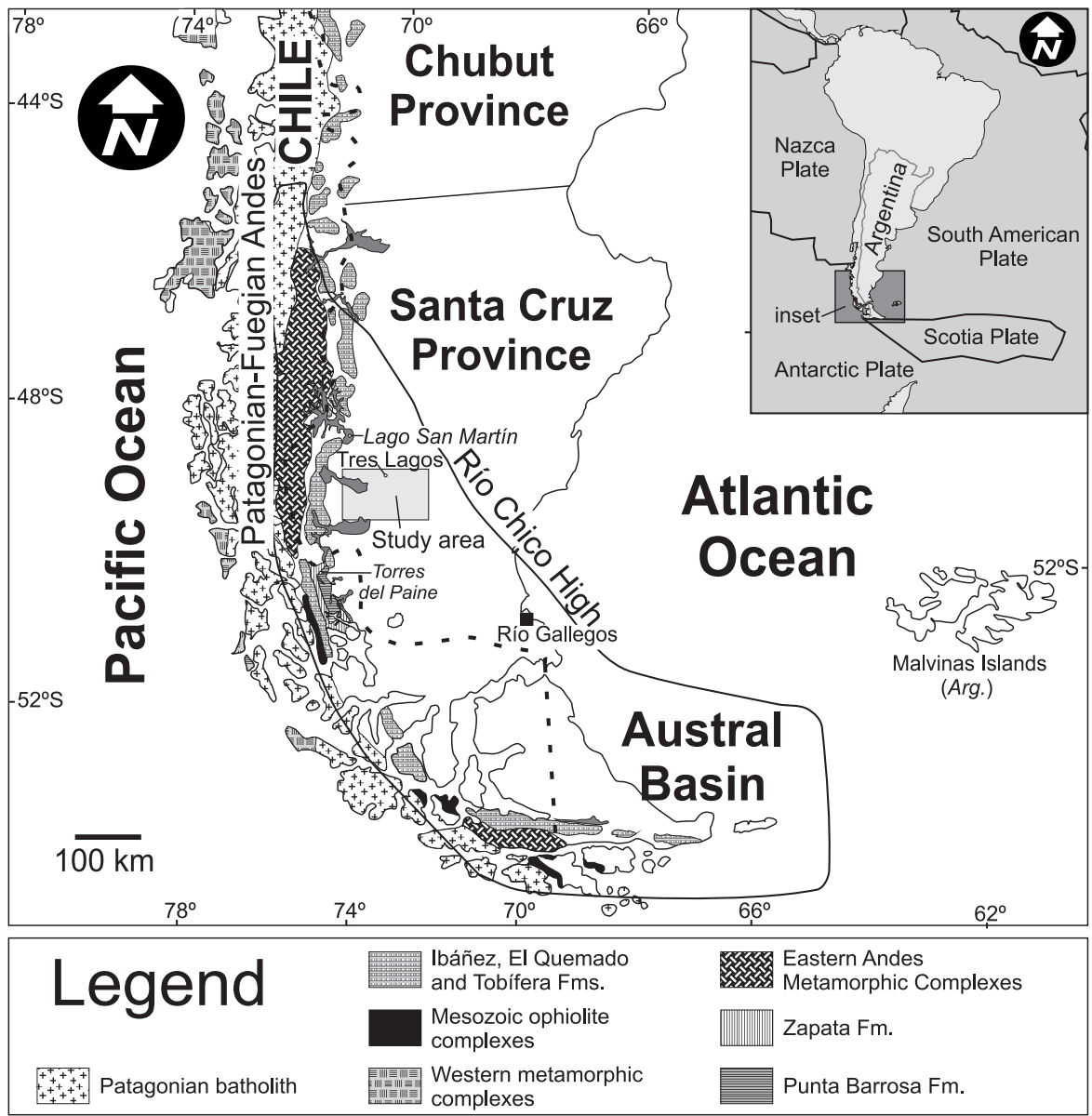

FIG. 1. Geological setting of the Austral Basin and location of the study area. Location map of the southwestern Patagonian geological units (modified from Hervé et al., 2007a, b; Calderón et al., 2007a, b; Fildani y Hessler, 2005).

characterised by rifting and sea-floor spreading along the western margin of the PatagonianFuegian Andes (Katz, 1963; Dalziel et al., 1974; Dalziel, 1981; Biddle et al., 1986; Calderón et al., 2007a). A change from regional extension to compression occurred in the mid-Cretaceous and produced a retroarc fold-thrust belt and linked foreland basin, known in Chile as Magallanes Basin (Biddle et al., 1986; Wilson, 1991; Fildani et al., 2003; Fildani and Hessler, 2005; Fosdick et al., 2011). The geological history of the Austral Basin in the study area is characterized by three main tectonic stages (Biddle et al., 1986; Robbiano et al., 1996; Ramos, 2002; Kraemer et al., 2002; Peroni et al., 2002; Rodríguez and Miller, 2005). These are the rift stage, the stage of thermal subsidence and, finally, the foreland stage (Fig. 2). The rift and thermal subsidence stages of the Austral Basin mainly coincide with the deposition of the Rocas Verdes Marginal Basin, whereas the foreland stage of the Austral Basin is simultaneous with the evolution of the Magallanes Basin.

\subsection{Rift Stage}

This rifting stage is connected to the breakup of Gondwana (Uliana and Biddle, 1988; Pankhurst et al., 2000), which took place during the Middle to Upper Jurassic, approximately $170 \mathrm{Ma}$ ago. It affected mainly the Deseado Massif and it is represented in the Patagonian-Fuegian Andes by the El Quemado Complex, which is known as the Tobífera Formation in Chile. The El Quemado 


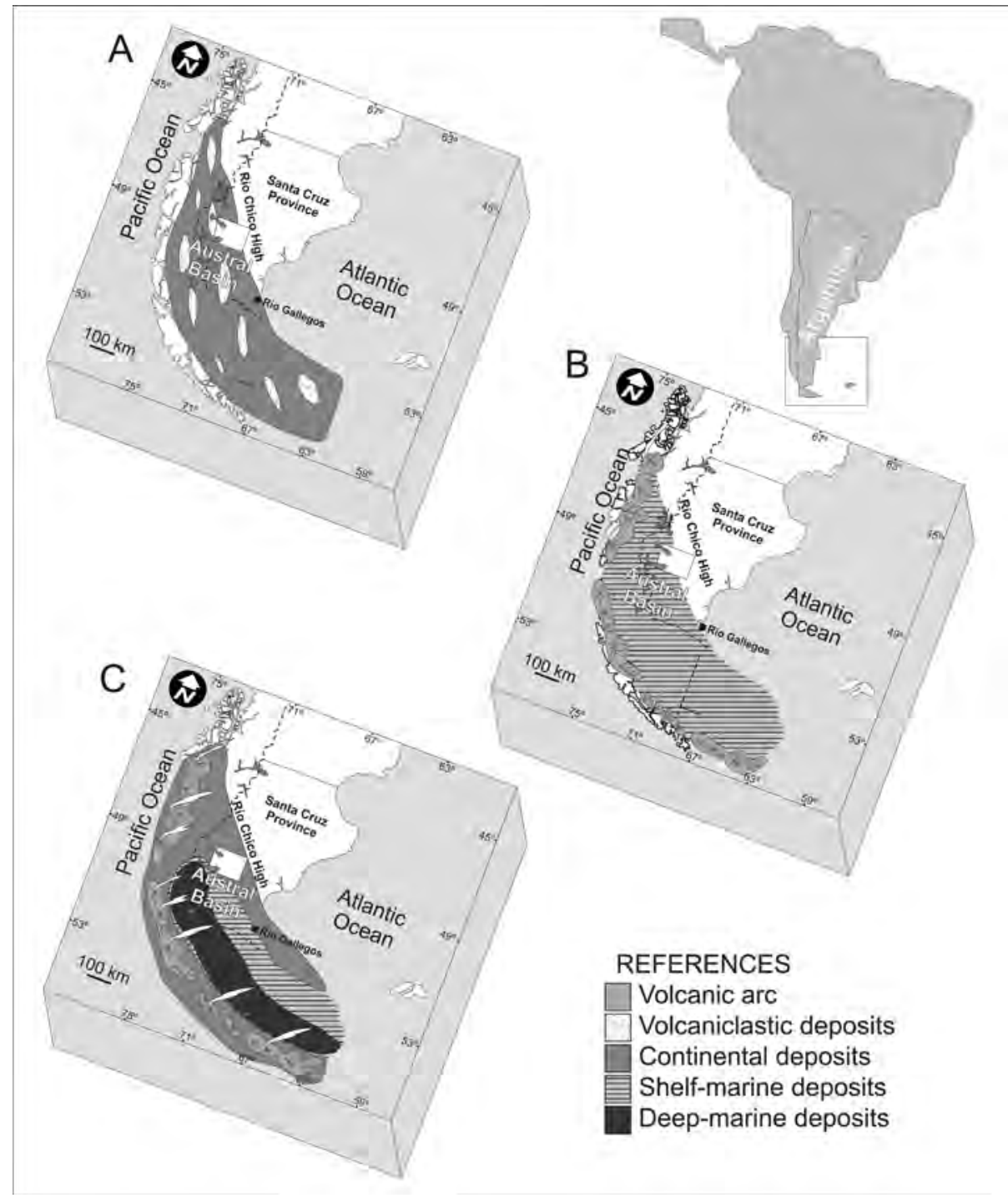

FIG. 2. Schematic stages of geological evolution of the Austral Basin from Middle Jurassic to the Cenozoic. a. Rift Stage (Middle to Upper Jurassic), characterized by rifting in a series of narrow grabens. b. Thermal Subsidence Stage (Upper Jurassic to Lower Cretaceous), once the tectonic activity ceased thermal subsidence began with a transgression that broadly overlapped the margins of the initial half-grabens. c. Foreland Stage (mid-Cretaceous to Cenozoic), occurrence of the Andean uplift, development of a foreland thrust belt and basin.

Complex consists of very thick layers of dacites and andesites controlled by direct faults and intercalated with conglomerates, sandstones and, in certain cases, even mudstones. In this initial stage, grabens and half-grabens developed, which were filled with volcaniclastic and volcanic rocks intercalated with epiclastic sediments (Biddle et al., 1986; Uliana and Biddle, 1988). The sediments become progressively younger towards the east.
To the south of the study area, this stage is characterized by rifting and sea-floor spreading along the western margin of the Patagonian-Fuegian Andes (Katz, 1963; Dalziel et al., 1974; Dalziel, 1981; Calderón et al., 2007a), which led to the development of a marginal basin (i.e., the Rocas Verdes Marginal Basin), connected to the opening of the Weddell Sea, in the southwestern section of the basin (Dalziel, 1981; Biddle et al., 1986). 


\subsection{Thermal Subsidence Stage}

Subsequently, once the tectonic activity had ceased the thermal subsidence stage began, the typical transgressive deposits of the Springhill Formation developed, characterized by quartz arenites with bipyramidal quartz clasts. The Springhill Formation broadly overlaps the margins of the initial halfgraben, and it was overlaid by a thick deep-marine succession, characterized by the alternating black mudstones and marls of the Río Mayer Formation, which extends to the Barremian. Towards the end of this cycle (early Aptian-Albian), in the northern and eastern sectors of the basin a large passive-margin delta system developed, referred to as the Piedra Clavada Formation, and its equivalent in the Lago San Martín area, the Kachaike Formation.

During this stage, to the south of the study area, the basin acts as a back-arc basin (Calderón et al., 2007a).

\subsection{Foreland Stage}

A regional change from an extensional to a compressional phase took place in the mid-Cretaceous, as a result of the convergence of an arc and/or a craton, thus causing the obduction of the ophioliteswhich constituted the sea floor of the Rocas Verdes Marginal Basin- over the cratonic continental margin (Dalziel, 1981; Ramos, 1989). It has not been possible to determine the exact timing of obduction, but the compression associated with the early stages of the orogeny caused the development of a retroarc fold-and-thrust belt along the Patagonian-Fuegian Andes (Ramos et al., 1982; Biddle et al., 1986; Wilson, 1991; Fildani et al., 2003; Fildani and Hessler, 2005). This fold-and-thrust belt is associated along its eastern margin with a foreland basin (Austral Foreland Basin). This compression process extended from the Upper Cretaceous to the Neogene (Ramos et al., 1982; Biddle et al., 1986; Wilson, 1991; Spalletti and Franzese, 2007; Fosdick et al., 2011).

Between the middle Cenomanian and the lower Coniacian (96-84 Ma), a deformation event occurred which could be related to the closure of the Rocas Verdes Marginal Basin (Ramos et al., 1982; Biddle et al., 1986). The onset of the compressional phase in the middle sector of the Austral Basin is characterized by the west to east progradation of the fluvial-estuarine facies of the
Mata Amarilla Formation (Varela, 2009, 2011). This change towards a compressional phase was also interpreted in the northern sector of the Lago Viedma (Lake Viedma), on the basis of paleocurrent data and facies changes in the Lago Viedma Formation, which is upper Albian to upper Cenomanian in age (Canessa et al., 2005). In Chile, on the other hand, in the region of the Torres del Paine National Park and in the Última Esperanza Province (Fig. 1), the compressional phase of the Magallanes Basin occurs in the transition from the Zapata Formation to the Punta Barrosa Formation, the former being a shelf marine environment, and the latter a deep-marine environment (Wilson, 1991; Fildani et al., 2003; Fildani and Hessler, 2005). The transition was dated by means of detrital zircons, and the age was estimated as being no older than $92 \pm 1$ Ma (Fildani et al., 2003). Recently, Fosdick et al. (2011) obtained new zircon U-Pb ages from an interbedded volcanic ash in the Zapata-Punta Barrosa transition, suggesting an age of $101 \pm 1$ Ma. They indicated that the deformation at $51^{\circ} 30^{\prime} \mathrm{S}$ began $\sim 100 \mathrm{Ma}$ and progressed during six main stages (Fosdick et al., 2011).

\section{Background to the Mata Amarilla Formation}

This succession has been referred to as Estratos de Mata Amarilla (Mata Amarilla Strata; Feruglio, in Fossa Mancini et al., 1938) or Mata Amarilla Formation (Leanza, 1972; Russo and Flores, 1972), and it coincides with the succession that Ameghino (1906) called Sehuenense [sic] (Cione et al., 2007; Varela et al., 2008; Varela, 2009; O’Gorman and Varela, 2010). It is one of the units that best exemplifies the early Late Cretaceous in the Austral Basin, which could be connected to the closure of the Rocas Verdes Marginal Basin (Biddle et al., 1986; Varela, 2009, 2011).

This formation has a maximum thickness of approximately $350 \mathrm{~m}$ in outcrops, and it is composed of gray and blackish siltstone and claystone, alternating with banks measuring between 1 and $10 \mathrm{~m}$ constituted by whitish and yellowish-grey fine- to medium-grained sandstone, deposited in littoral and continental environments (Arbe, 1989, 2002; Poiré et al., 2004; Russo and Flores, 1972; Russo et al., 1980; Varela and Poiré, 2008; Varela et al., 2008; Varela, 2009, 2011). According to the classification of Folk et al. (1970), the sandstones of the Mata 
Amarilla Formation are feldspathic litharenites, except for three samples which were labelled as lithic feldarenites (Varela, 2011). The petrographic study of 48 thin sections concluded that the main provenance of the sandstones of the Mata Amarilla Formation derives from a magmatic arc and, to a lesser extent, from an orogenic area (Varela, 2011). The type section is located on the southern margin of the Río Shehuen or Chalía, approximately 23 km east of the locality of Tres Lagos, in the area surrounding the Estancia Mata Amarilla, also known as Estancia La Soriana, (locality 3, Fig. 3). It overlies the Piedra Clavada Formation, which is lower Albian in age, with transitional contact and it is unconformably covered by the Campanian sediments of the La Anita Formation (Varela and Poiré, 2008; Varela, 2009, 2011) (Fig. 4). This formation (see Fig. 4) was deposited during the early Upper Cretaceous, extending from the Cenomanian to the Santonian (Poiré et al., 2007; Varela and Poiré 2008; Varela, 2009).

On the basis of facies analysis, Varela (2009, 2011) recently divided the Mata Amarilla Formation into three sections, according to the different conditions of accommodation space creation with respect to sediment supply (Fig. 4).

The lower section of the Mata Amarilla Formation consists of fine-grained sediments with palaeosol development interbedded with laminated shale and coquinas. In the eastern part of the study area, eight littoral facies associations or sedimentary units were recognised: sabulithic bars, large-scale bars, bioclastic lobes, sand bars with herringbone cross-stratification, sand bars with hummocky cross-stratification, smallscale gravelly channels and diamictites, fine-grained sediments with shells, and heterolithic deposits with marine fossils. These facies associations correspond to littoral marine, lagoon, estuary, and bayhead delta palaeoenvironments (Varela, 2011). In turn, in the western sector of the study area, the facies associations identified were large-scale simple ribbons and fine-grained sedimentation, which is consistent with a distal fluvial system, with palaeocurrents coming from the west (Varela, 2011).

The middle section of the Mata Amarilla Formation is characterized by conglomerates, sandstones, siltstones and mudstones. In the western part of the study area, four facies associations or sedimentary units were defined: gravelly sheets, sandy sheets, small-scale bars and fine-grained sedimentation. These correspond, from west to east, to a gravel-bed braided fluvial system and a sandy high-sinuosity meandering fluvial system (Varela, 2011). The palaeocurrents indicate flow from west to east, into the main fluvial system located to the east. In the eastern part of the study area six facies associations were recognised: complex ribbons, small-scale simple ribbons, small-scale bars, lobes, fine-grained sedimentation, and heterolithic deposits with continental fossils. These are associated with a low-sinuosity meandering fluvial system with aggradation, which is the main drainage system, and the palaeocurrents indicate flow from the northeast to the southwest (Varela, 2011).

As regards the upper section of the Mata Amarilla Formation, it is similar to the lower section, as it consists of fine-grained sediments with palaeosol development interbedded with laminated shale and coquinas (Varela, 2011). In the eastern part of the study area, facies associations or sedimentary units identified-i.e., bioclastic lobes, sand bars with herringbone cross-stratification, fine-grained sediments with shells, and heterolithic deposits with marine fossils-correspond to littoral marine, lagoon, and estuary palaeoenvironments (Varela, 2011). The western sector of the study area is characterized by two facies associations or sedimentary units: large-scale simple ribbons and fine-grained sediments, which can be assigned to a distal fluvial system, with palaeocurrents coming from the west (Varela, 2011).

The lower and upper sections show conditions with high rates of accommodation/sediment supply, whereas the middle section shows low rates of accommodation/sediment supply (Varela, 2009, 2011). These changes are inferred to be promoted by relative sea-level oscillations in response to the tectonic evolution of the Austral fold-and-thrust belt (Varela, 2009, 2011).

\section{Problems of dating on the basis of fossil content}

Despite the abundant fossil content of the Mata Amarilla Formation, a considerable number of doubts and debates have arisen concerning the age 


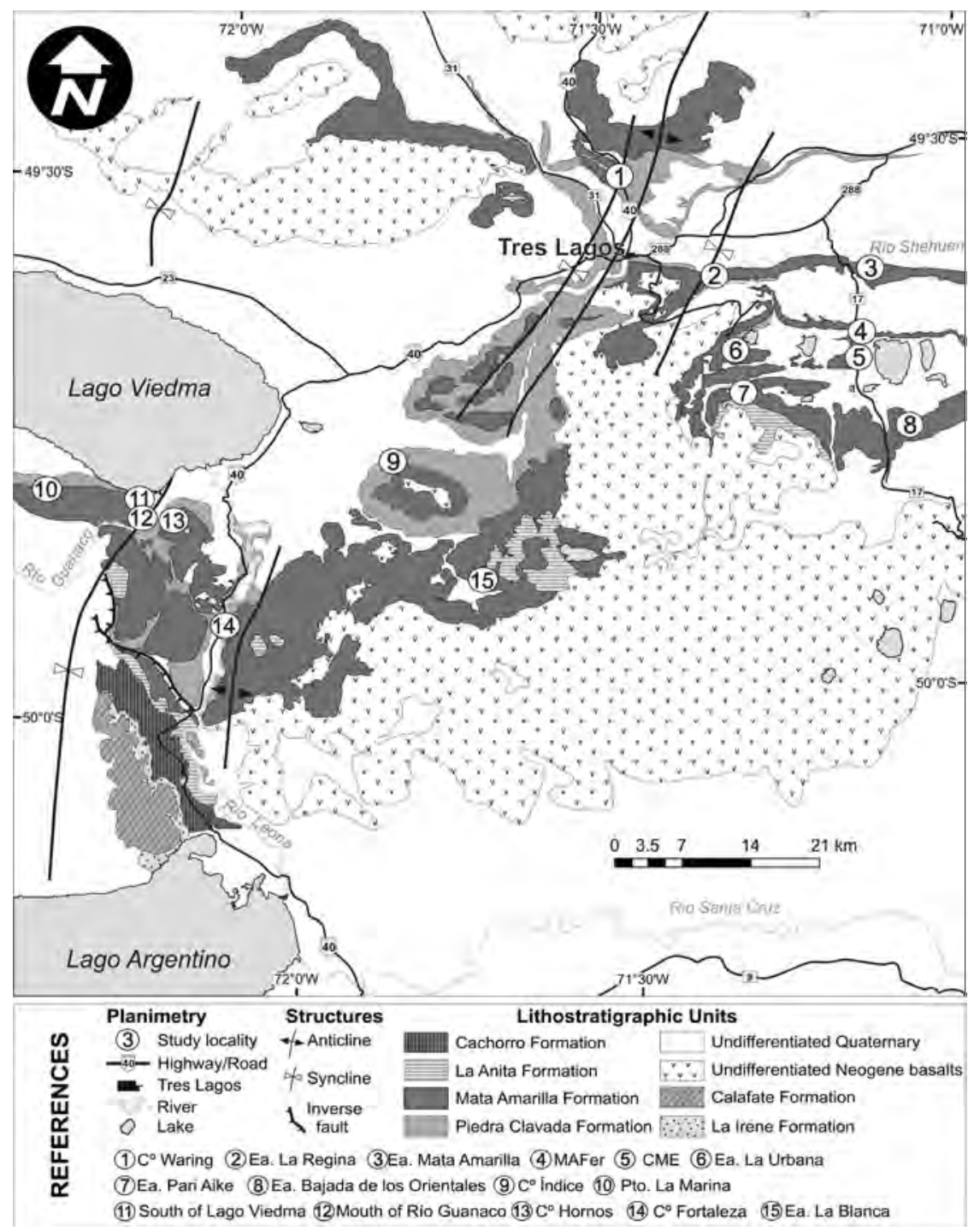

FIG. 3. Geological map of the study area showing the Cretaceous units of the Austral Basin (after Varela, 2011).

of this formation. On one hand, Exogyra guaranitica, Pterotrigonia aliformis, Corbula sehuena, and the gastropod Potamides (Pirenella) patagoniensis (Ihering, 1907; Wilckens, 1907; Feruglio, 1936, 1937, 1938; Piatnizky, 1938; Griffin and Varela, 2012) present in these rocks are not index fossils which could be used to determine ages and/or limit options. Yet, this association suggests a Coniacian age (e.g., Riccardi and Rolleri, 1980).

The most reliable chronological information is given by the presence of ammonites at Cerro Índice (Índice Hill, locality 9, Fig. 3), which are assigned to the 'Estratos' de Mata Amarilla and were placed in a new species of the genus Peroniceras (P. santacrucense) (Leanza, 1970). Subsequently, Blasco et al. (1980) and Nullo et al. (1981) described specimens of Placenticeras sp. in the Mata Amarilla Formation at Cerro Índice, and regarded them as Santonian in age. On the basis of the few specimens found by Leanza (1970) in the locality mentioned above, Riccardi (1984a, b) described the faunule of Peroniceras santacrucense, assigning it a Coniacian age. Riccardi et al. (1987) relocated the species to the genus Gauthiericeras, adding that it occurs 


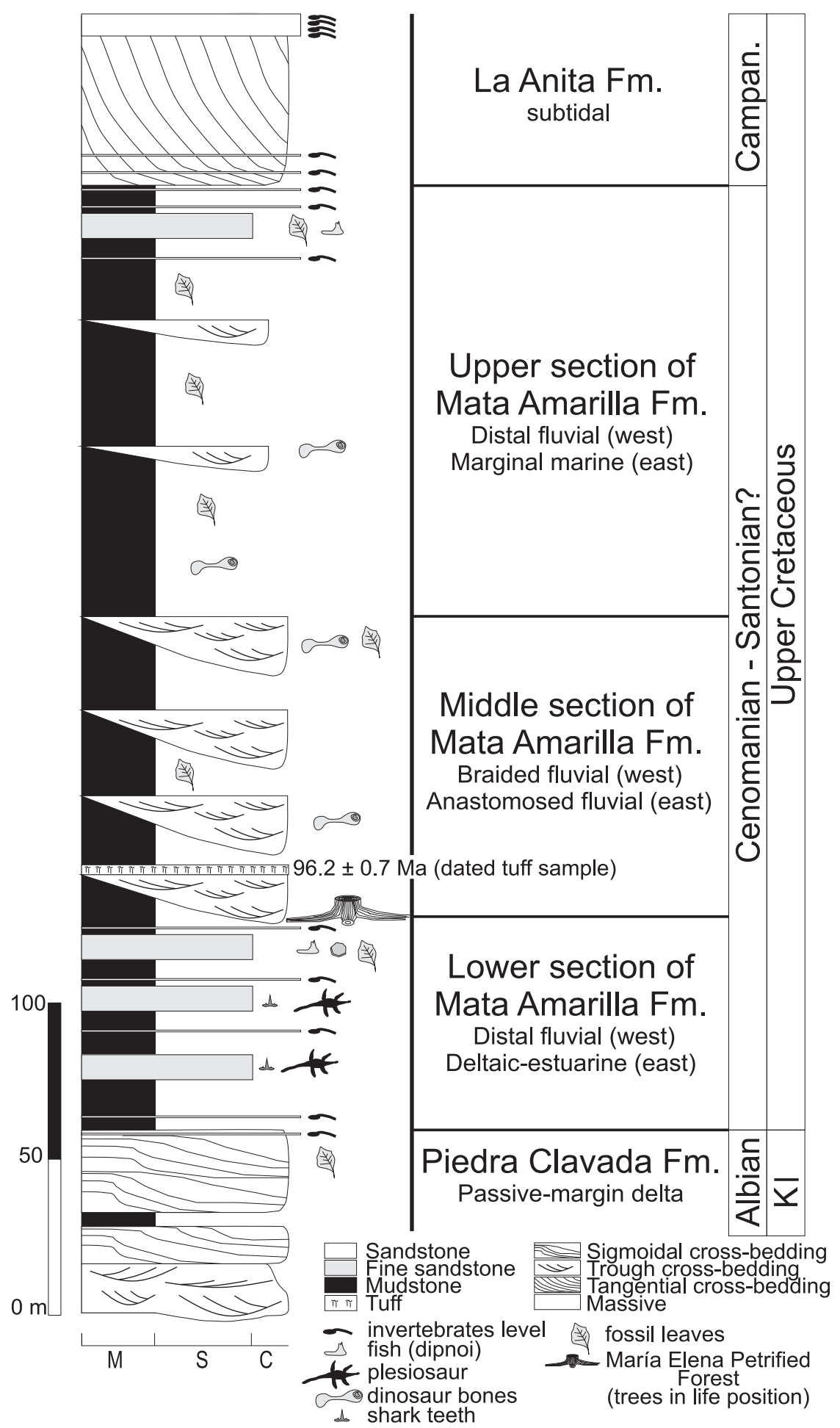

FIG. 4. Schematic stratigraphic-section of the three Mata Amarilla Formation sections and their relationship to the over- and underlying units. Location of the tuff layer dated is indicated in the cross-section. 
approximately $75 \mathrm{~m}$ above levels with Placenticeras and approximately $20 \mathrm{~m}$ below the point of contact with the Pari Aike Formation (currently regarded as the middle section of the Mata Amarilla Formation; Varela, 2011). In turn, they found ammonites in the Bajo del Cerro Índice (Cerro Índice Depression) which belong to the same species (Gauthiericeras santacrucense), and located this faunule to the upper Coniacian, according to the stratigraphic distribution of the genus Gauthiericeras (Riccardi et al., 1987). Finally, Riccardi (2002) established the Gauthiericeras santacrucense zone and dated it as late Coniacian, in agreement with the stratigraphic range of the genus Gauthiericeras suggested by Grossouvre (Riccardi, 2002). Regardless of the exact stratigraphic location of the ammonite-bearing level or levels, it is difficult to locate them in any of the three sections of the Mata Amarilla Formation, as they have not been found during the field work.

On the other hand, vertebrates provide inconsistent and partially contradictory data (Goin et al., 2002; Varela, 2011); such is the case for dinosaurs, among which the most prominent are the Ornithischia Talenkauen santacrucensis Novas, Cambiaso, and Ambrosio, 2004; the theropod Orkoraptor burkei Novas, Ezcurra and Lecuona, 2008; and the sauropod Puertasaurus reuili Novas, Salgado, Calvo and Agnolín, 2005 (Lacovara et al., 2004; Novas et al., 2004a, 2004b, 2005, 2008). They were assigned to the Maastrichtian following the stratigraphic criteria of Kraemer and Riccardi (1997). What caused persistent doubts was the presence of large sauropods such as Puertasaurus reuili, which were extinct worldwide towards the end of the Santonian (Novas, personal communication). The occurrence of Carcharodontosaurus teeth (Novas et al., 1999), which were found in Cenomanian units in Argentina and Africa, suggests similar ages. In this regard, Ameghino (1899) described at the Cerro Pari Aike (Pari Aike Hill, locality 7, Fig. 3) -currently referred to as the Mata Amarilla Formation, following Varela, 2011-a Loncosaurus argentinus, a primitive ornithopod similar to Talenkauen santacrucensis discovered at Cerro Hornos (Hornos Hill, locality 13, Fig. 3). These ornithopods from the Santa Cruz Province, in turn, bear similarities with those found in Cenomanian to Santonian units in other Patagonian regions (Novas et al., 2002).

The record of the turtle family Chelidae in South America ranges from the Albian until today (Broin and de la Fuente, 1993; de la Fuente et al., 2001; Lapparent de Broin and de la Fuente, 2001). The turtles collected in the lower section of the Mata Amarilla Formation, at the Estancia Bajada de los Orientales (Bajada de los Orientales Farm, locality 8) and the Estancia Mata Amarilla (locality 3, Fig. 3) have much in common with various taxa that constitute the Campanian-Maastrichtian cheloniafauna (Goin et al., 2002).

Lungfish (Dipnoi) were described by Cione et al. (2007) based on 200 complete and partial tooth plates. These authors described two 'Ceratodus' iheringi species and a new genus, Atlantoceratodus iheringi Cione et al., 2007, which is similar to the 'Ceratodus' madagascariensis Priem 1924 of the Upper Cretaceous (Campanian) from Madagascar, to the extent that they are regarded as belonging to the same genus.

Recently found plesiosaur remains have been studied by O'Gorman and Varela (2010), who compared them with the diagnosis of Polyptychodon patagonicus described by Ameghino (1893). The remains found in the lower section of the Mata Amarilla Formation at the Estancia Mata Amarilla (locality 3) and Estancia La Blanca (locality 15, Fig. 3) include some vertebrae, a propodium and over 56 teeth which could be assigned to Plesiosauria indet. and Elasmosauridae indet., and can be compared to the plesiosaurs of the Cenomanian from Antarctica and Australia (O'Gorman and Varela, 2010).

Regarding the flora, Berry (1928) described several leaf impressions of species such as 'Adiantum' patagonicum (erroneously classified as a fern as it belongs to the 'Ginkgoites'; Iglesias, personal communication), the conifer Fitzroya tertiaria, and eight species of angiosperms (Rollinia patagonica, Hydrangea incerta, Sterculia washburnii, Peumus clarki, Laurelia amarillana, Laurophyllum chalianum, Apocynophyllum chalianum, Bignonites chalianus, Phyllites sp.). On the basis of this relatively high diversity of Cretaceous angiosperms, Berry (1928) erroneously dated it as Cenozoic (Oligocene-Miocene; fide Frenguelli, 1953). In turn, Iglesias et al. (2007, 2009) described an abundant angiosperm taphoflora in the lower and middle sections of the Mata Amarilla Formation, at the Estancia Mata Amarilla (locality 3) and Mafer (locality 4, Fig. 3), which was attributed to the adaptive radiation of that group of plants during the Cenomanian. 
The trunks of the María Elena Petrified Forest are almost exclusively gymnosperms of the Podocarpaceae family and, to a lesser extent, Araucariaceae (Zamuner et al., 2004, 2006, 2008), they do not have biostratigraphic value.

In short, the chronological information provided by invertebrates, theropod dinosaurs and sauropods, fish, turtles, plesiosaurs, and fossil flora does not coincide. Owing to this, and to the lack of radiometric data, the need to have a reliable age which would dispel all doubts on the age of the Mata Amarilla Formation has become of the utmost importance.

\section{Methodology}

In order to obtain a reliable radiometric age which would solve the problem concerning the age of the formation, a sample was collected from a primary tuff located $29 \mathrm{~m}$ above the point of contact between the lower and middle sections of the Mata Amarilla Formation, at the Estancia Mata Amarilla (locality 3, Figs. 3 and 4).

Zircon crystals from the primary tuff sample were recovered from a heavy mineral concentrate by hand-picking under a binocular microscope. Once extracted, they were mounted and polished to approximately half their thickness. The crystals were observed and imaged by cathodoluminescence (CL) using a Jeol JSM-6490 scanning electron microscope (SEM) equipped with a Gatan MiniCL detector at the Goethe-Universität Frankfurt am Main (GUF), in Germany. The U-Th-Pb analyses were performed at the GUF using a sector field inductively coupled plasma mass spectrometer (SFICP-MS) coupled with a new ultraviolet (UV) laser ablation system, the New Wave Research UP-213, with a teardrop-shaped, low-volume $\left(<2.3 \mathrm{~cm}^{3}\right)$ laser cell. The instrument setup and the analytical method used in this study were described in detail by Gerdes and Zeh (2006, 2009), and Frei and Gerdes (2009). Analytical spots (30 $\mu \mathrm{m}$ in diameter) were chosen on the basis of the internal structure of the grains, as observed in the CL images. Raw data were corrected for background signal. Common $\mathrm{Pb}$, laserinduced elemental fractionation, instrumental mass bias, and time-dependent elemental fractionation of $\mathrm{Pb} / \mathrm{U}$ were calculated using an Excel $^{\odot}$ spreadsheet (Gerdes and Zeh, 2006). Drift-correction was performed by fitting a linear regression through all measured ratios, excluding the outliers $( \pm 2$ standard deviation, $2 \sigma$ ), and using the intercept with the $y$-axis as the initial ratio. The laser-induced elemental fractionation and instrumental mass bias were corrected by normalization to the reference zircon GJ-1 (at GUF, ID-TIMS U-Pb age 608 \pm 1 Ma). Reported uncertainties $(2 \sigma)$ of the ${ }^{206} \mathrm{~Pb} /{ }^{238} \mathrm{U}$ were propagated by quadratic addition of the external reproducibility (2SD, standard deviation) obtained from the GJ-1 zircon during each analytical session and the within-run precision of each analysis (2SE, standard error). In the case of the ${ }^{207} \mathrm{~Pb} /{ }^{206} \mathrm{~Pb}$ ratio, a ${ }^{207} \mathrm{~Pb}$ signal-dependent uncertainty propagation was used (Gerdes and Zeh, 2009). The accuracy of the method was verified by means of the analysis of reference zircons $91.500(1064.8 \pm 4.3 \mathrm{Ma}$, MSWD of concordance and equivalence $=0.86$ ), Plešovice (337.7 $\left.\pm 1.6 \mathrm{Ma}, \mathrm{MSWD}_{\mathrm{C}+\mathrm{E}}=0.84\right)$, and Temora (416.6 $\pm 2.5 \mathrm{Ma}, \mathrm{MSWD}_{\mathrm{C}+\mathrm{E}}=0.9$ ). Plots and age calculations were made using the ISOPLOT software (Ludwig, 2003).

\section{Tuff level}

The tuff level is located $29 \mathrm{~m}$ above the contact between the lower and middle sections of the Mata Amarilla Formation, at the Estancia Mata Amarilla (locality 3, Figs. 3 and 4). This tuffaceous level is $60 \mathrm{~cm}$ thick, massive and white coloured, and it is interbedded with fine-grained floodplain deposits with abundant palaeosol development (Fig. 5a). The tuff has no overimposed pedogenesis, its grain size is very fine to fine (Fig. 5b), and based on its fragmental composition it could be classified as a vitric tuff with minor crystal content (Fig. 5c). Even though this level has lateral continuity in locality 3 (Estancia Mata Amarilla) and other tuff levels which display no pedogenesis were found in other localities, the nature of the fluvial palaeoenvironment prevents its direct correlation. Added to this, all palaeosols of the Mata Amarilla Formation are composed almost entirely of smectite clays, which have a genesis associated with the alteration of volcanic glass (Varela, 2010, 2011).

\section{Radiometric data}

Cathodoluminescence studies on the prismatic zircon crystals from the tuff revealed that their growth is characterized by oscillatory zoning, which 


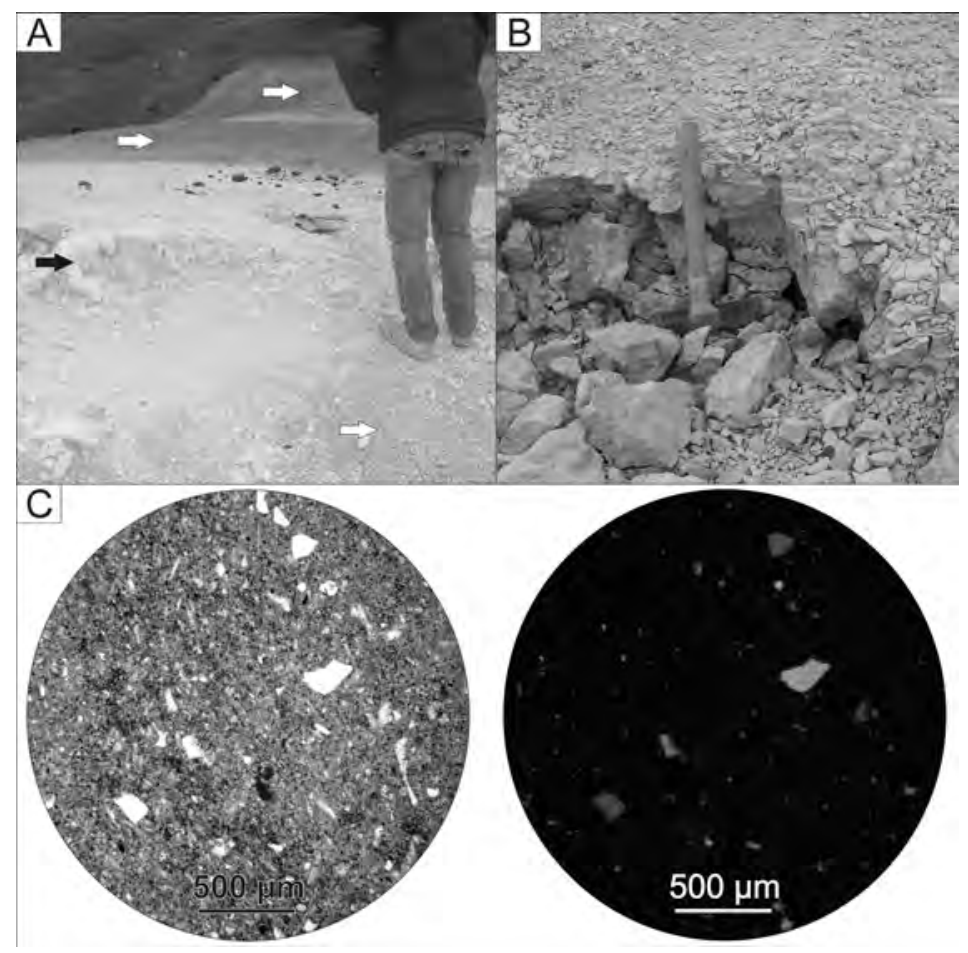

FIG. 5. a. Photograph of the tuff layer of the middle section of the Mata Amarilla Formation at Estancia Mata Amarilla (black arrow), interbedded with fine-grained floodplain deposits with palaeosol development (white arrows); b. Detail of the tuff level, where the massive structure and very fine to fine grain size can be observed (hammer for scale is $33 \mathrm{~cm}$ long); c. Microphotographs of the tuff, without polarised light (left), showing ash glass and crystals; and with polarised light (right), only crystals can be distinguished due to the isotropic nature of volcanic glass.

is typical for primary volcanic crystals. It could be observed that certain crystals were fractured at right angles, which could be connected to eruptive violence, that is, clast collision during the eruptive event (Fig. 6). On occasion, rounded inherited cores could be distinguished, characterized by a darker luminescence (Fig. 6). Xenocrystic zircon typically shows signs of resorption and original oscillatory zoning is blurred or obliterated (Fig. 6). In this manner, twenty U-Pb spot analyses by laser ablation were carried out on the outer parts of the zoned zircon crystals (Table 1 ), which yielded a concordia age of $96.23 \pm 0.71 \mathrm{Ma}$ (Fig. 7A). This age is interpreted as dating the crystallisation of zircons from the tuff layer and, as it constitutes a primary deposit, it coincides with the time of deposition of the middle section of the Mata Amarilla Formation.

Fifteen ages older than 100 Ma were obtained: 6 spot analyses by laser ablation were carried out on zircon cores with younger overgrowth rims and
8 spot analyses were obtained on xenocrystic zircon (Table 1). The datings of the inherited zircon cores and xenocrystic zircon suggest crustal involvement, and three magmatic and/or metamorphic events prior to the eruption that deposited the tuff were registered. These are, in increasing order of age, a lower Permian event (280-300 Ma), a Lower Jurassic event (180-200 Ma) and finally a younger group of ages indicating an Upper Jurassic event ( 157 Ma, Fig. 6B).

\section{Discussion}

The new dating of the Mata Amarilla Formation indicates the occurrence of magmatism at $96.2 \pm 0.7$ Ma, which would be located to the west of the study area. This magmatic arc may have been active both during the thermal subsidence stage and the foreland stage (Fig. 2). However, on the basis of the sedimentological data -which indicate 


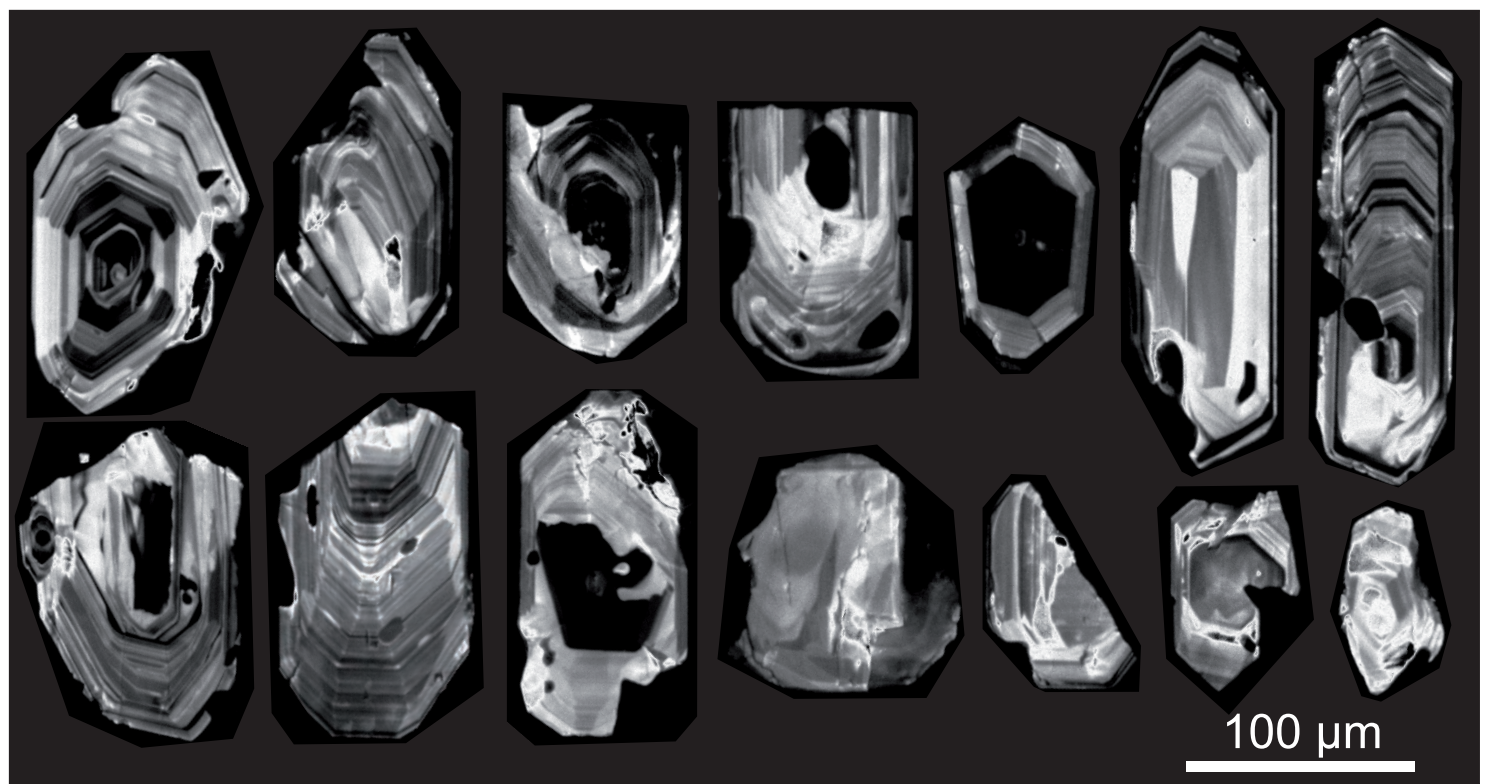

FIG. 6. Photographs of zircon crystals zoned under cathodoluminescence; note their prismatic shape and fractured edges.
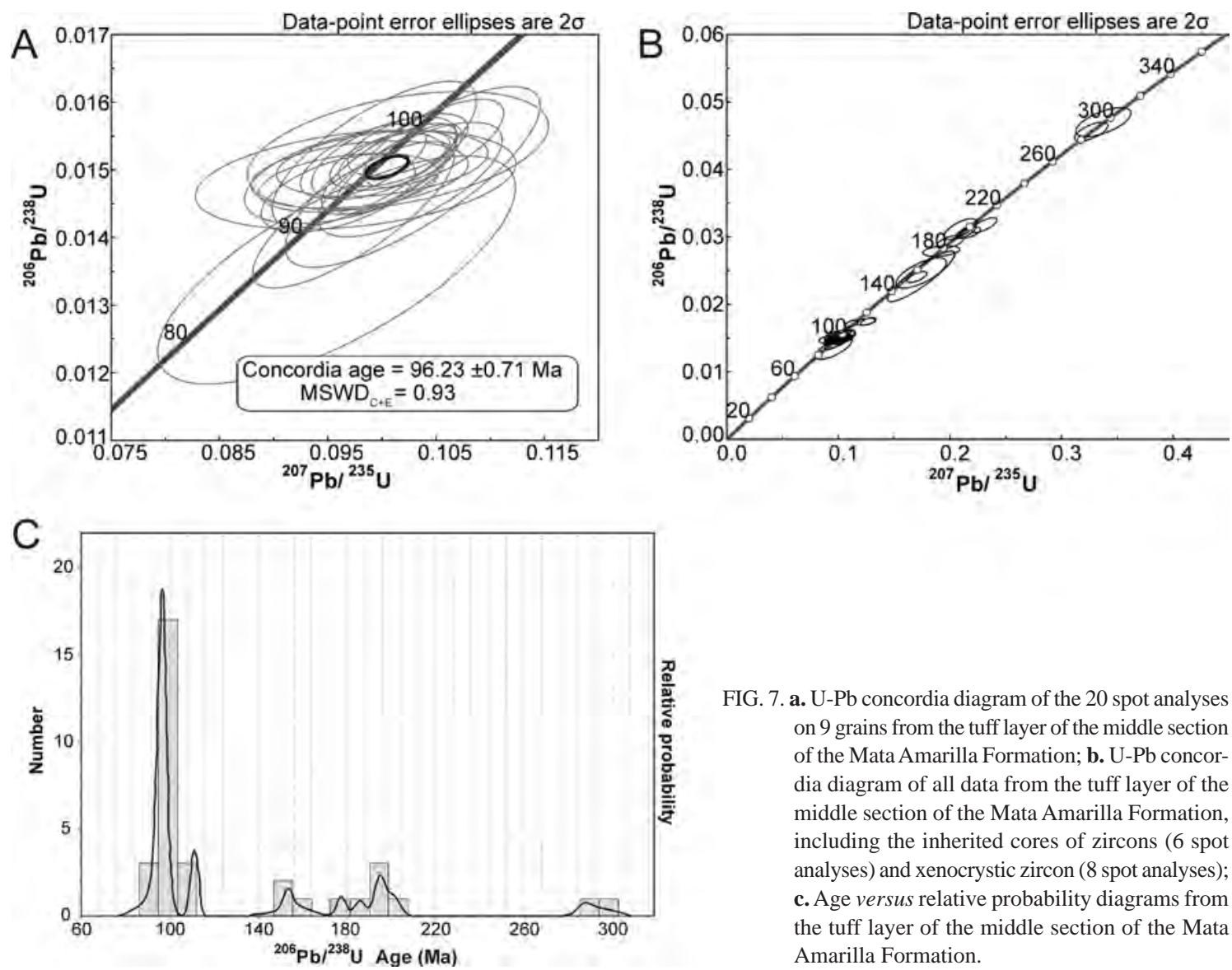

FIG. 7. a. U-Pb concordia diagram of the 20 spot analyses on 9 grains from the tuff layer of the middle section of the Mata Amarilla Formation; b. U-Pb concordia diagram of all data from the tuff layer of the middle section of the Mata Amarilla Formation, including the inherited cores of zircons (6 spot analyses) and xenocrystic zircon (8 spot analyses); c. Age versus relative probability diagrams from the tuff layer of the middle section of the Mata Amarilla Formation. 
TABLE 1. DATA FROM ISOTOPIC ANALYSIS BY LASER ABLATION OF 35 SPOT ANALYSES FROM TUFF LAYER (MIDDLE SECTION, MATAAMARILLA FORMATION).

\begin{tabular}{|c|c|c|c|c|c|c|c|c|c|c|c|c|c|c|c|c|c|}
\hline spot & grain & $\begin{array}{c}{ }^{207} \mathbf{P b}^{\mathbf{a}} \\
\text { (cps) }\end{array}$ & $\begin{array}{c}\mathrm{U}^{\mathrm{b}} \\
(\mathrm{ppm})\end{array}$ & $\begin{array}{c}\mathbf{P b}^{\mathbf{b}} \\
(\mathbf{p p m})\end{array}$ & $\frac{\mathbf{T h}}{\mathbf{U}}^{\mathrm{b}}$ & ${ }^{206} \underline{\mathrm{Pb}}$ & ${ }^{{ }^{206} \underline{P b}^{\mathrm{C}}}{ }^{\mathrm{U}}$ & $\begin{array}{l} \pm 2 \sigma \\
(\%)\end{array}$ & ${ }^{2307} \underline{\mathbf{P b}}^{\mathbf{C}}$ & $\begin{array}{l} \pm 2 \sigma \\
(\%)\end{array}$ & ${ }^{206} \underline{\mathbf{P b}}^{\mathrm{P}}$ & $\begin{array}{l} \pm 2 \sigma \\
(\%)\end{array}$ & rho $^{\mathrm{e}}$ & ${ }^{238} \underline{\mathrm{Pb}}$ & $\begin{array}{c} \pm 2 \sigma \\
\text { (Ma) }\end{array}$ & ${ }^{235} \underline{\mathrm{Pb}}$ & $\begin{array}{l} \pm 2 \sigma \\
\text { (Ma) }\end{array}$ \\
\hline a1 & c, gr3 & 1898 & 212 & 7 & 0.46 & 8809 & 0.029 & 2.7 & 0.20 & 5.0 & 0.050 & 4.2 & 0.55 & 186 & 5 & 185 & 8 \\
\hline $\mathrm{a} 2$ & c, gr4 & 5254 & 374 & 17.8 & 1.49 & 44063 & 0.046 & 2.5 & 0.326 & 3.8 & 0.052 & 2.8 & 0.66 & 287 & 7.0 & 287 & 9 \\
\hline a3 & gr1 & 685 & 153 & 2 & 0.47 & 3602 & 0.015 & 3.2 & 0.096 & 6.1 & 0.047 & 5.1 & 0.53 & 94 & 3.0 & 93 & 5 \\
\hline $\mathrm{a} 4$ & gr1 & 847 & 187 & 2.8 & 0.30 & 2734 & 0.015 & 3.8 & 0.097 & 7.9 & 0.047 & 7.0 & 0.48 & 95.3 & 3.6 & 93.7 & 7.1 \\
\hline a5 & gr2 & 973 & 229 & 4.1 & 0.34 & 4266 & 0.014 & 10.2 & 0.096 & 14.1 & 0.051 & 9.8 & 0.72 & 86.6 & 8.8 & 92.9 & 12.6 \\
\hline a6 & c, gr5 & 1874 & 210 & 6.3 & 1.98 & 16535 & 0.031 & 2 & 0.217 & 4 & 0.051 & 3.1 & 0.58 & 194.5 & 4.3 & 199.4 & 7 \\
\hline a7 & x, gr6 & 1262 & 243 & 4.6 & 0.58 & 2340 & 0.017 & 2.5 & 0.112 & 4.4 & 0.047 & 3.6 & 0.57 & 110 & 2.7 & 108 & 4.5 \\
\hline a8 & gr1 & 1118 & 246 & 3.9 & 0.50 & 2233 & 0.015 & 2.9 & 0.098 & 4.8 & 0.047 & 3.8 & 0.61 & 97 & 2.8 & 95 & 4,4 \\
\hline a9 & r, gr5 & 1894 & 432 & 7.7 & 0.76 & 3319 & 0.015 & 3.3 & 0.100 & 5.4 & 0.048 & 4.3 & 0.60 & 97.1 & 3.2 & 96.9 & 5.0 \\
\hline a10 & x, gr7 & 3867 & 289 & 13.1 & 0.59 & 33624 & 0.047 & 3.7 & 0.337 & 6.0 & 0.052 & 4.7 & 0.63 & 296.1 & 10.8 & 295.2 & 15.4 \\
\hline a11 & gr8 & 1008 & 238 & 5 & 0.55 & 5618 & 0.015 & 4.7 & 0.103 & 6.8 & 0.050 & 4.9 & 0.69 & 95 & 4 & 99 & 6 \\
\hline a12 & gr8 & 675 & 162 & 2.5 & 0.38 & 2734 & 0.015 & 2.7 & 0.098 & 8 & 0.048 & 7.9 & 0.32 & 95.5 & 2.6 & 95 & 8 \\
\hline a13 & gr8 & 1706 & 443 & 7.2 & 0.51 & 15756 & 0.015 & 2.3 & 0.101 & 4.7 & 0.048 & 4.1 & 0.50 & 96.8 & 2.3 & 97.7 & 4.4 \\
\hline a14 & c, gr9 & 1612 & 226 & 6.3 & 0.29 & 14630 & 0.028 & 2.3 & 0.192 & 7.0 & 0.050 & 6.7 & 0.32 & 177.4 & 4.0 & 178.4 & 11.6 \\
\hline a15 & gr10 & 1326 & 361 & 5.5 & 0.44 & 9597 & 0.015 & 2.4 & 0.097 & 7.0 & 0.047 & 6.6 & 0.34 & 95 & 2.2 & 94 & 6 \\
\hline a16 & x, gr11 & 2078 & 324 & 8.8 & 0.29 & 18184 & 0.025 & 7.4 & 0.174 & 10.6 & 0.051 & 7.6 & 0.70 & 157.0 & 11.5 & 163.0 & 16.1 \\
\hline a17 & gr10 & 1613 & 404 & 8.2 & 1.51 & 3254 & 0.015 & 2.2 & 0.101 & 4.2 & 0.048 & 3.5 & 0.53 & 97 & 2 & 98 & 4 \\
\hline a18 & gr10 & 1581 & 424 & 8.4 & 1.37 & 12004 & 0.015 & 2.4 & 0.102 & 4.4 & 0.048 & 3.7 & 0.55 & 98.3 & 2.4 & 99.0 & 4.2 \\
\hline a19 & gr12 & 1163 & 332 & 6.3 & 0.47 & 11123 & 0.015 & 5.8 & 0.099 & 7.8 & 0.047 & 5.2 & 0.74 & 97.4 & 5.6 & 96.1 & 7.2 \\
\hline a20 & gr13 & 1302 & 376 & 6.0 & 0.61 & 11725 & 0.014 & 6.2 & 0.097 & 7.8 & 0.049 & 4.8 & 0.79 & 91.8 & 5.6 & 94.3 & 7.1 \\
\hline a21 & gr13 & 2103 & 592 & 9.8 & 0.41 & 18936 & 0.015 & 7.3 & 0.103 & 9.3 & 0.050 & 5.8 & 0.78 & 95.3 & 6.9 & 99.4 & 8.9 \\
\hline $\mathrm{a} 22$ & gr14 & 906 & 252 & 3.7 & 0.30 & 3650 & 0.015 & 4.0 & 0.098 & 12.4 & 0.048 & 11.7 & 0.33 & 95.1 & 3.8 & 94.5 & 11.2 \\
\hline a23 & x, gr15 & 4814 & 840 & 19.8 & 0.56 & 10137 & 0.024 & 2.7 & 0.170 & 4.2 & 0.051 & 3.2 & 0.65 & 153.3 & 4.1 & 160 & 6 \\
\hline $\mathrm{a} 24$ & gr16 & 680 & 158 & 2 & 0.36 & 985 & 0.015 & 2.6 & 0.100 & 8.0 & 0.048 & 7.5 & 0.33 & 97 & 2.5 & 97 & 7 \\
\hline a25 & r, gr17 & 1788 & 533 & 10.3 & 1.11 & 16389 & 0.015 & 3.5 & 0.105 & 5.0 & 0.049 & 3.7 & 0.69 & 98.5 & 3.4 & 101.2 & 4.9 \\
\hline a26 & c, gr18 & 1374 & 234 & 7 & 0.80 & 4000 & 0.024 & 12.7 & 0.174 & 14.2 & 0.052 & 6.3 & 0.90 & 153.7 & 19.3 & 163 & 22 \\
\hline a28 & gr16 & 1274 & 382 & 5.6 & 0.18 & 4396 & 0.015 & 5 & 0.101 & 11 & 0.048 & 10.2 & 0.42 & 98 & 5 & 98 & 11 \\
\hline a29 & x, gr19 & 5063 & 711 & 21.2 & 0.79 & 13997 & 0.032 & 2.8 & 0.231 & 4.0 & 0.053 & 2.8 & 0.72 & 201.5 & 5.6 & 211 & 8 \\
\hline a30 & gr20 & 1036 & 307 & 5 & 0.13 & 2733 & 0.015 & 3.6 & 0.102 & 4.7 & 0.049 & 3.0 & 0.77 & 96 & 3.5 & 98 & 4.4 \\
\hline a31 & c, gr21 & 3794 & 1005 & 17.4 & 1.93 & 25841 & 0.018 & 2.7 & 0.127 & 4.5 & 0.053 & 3.6 & 0.60 & 111.8 & 3.0 & 121.2 & 5.1 \\
\hline a32 & r, gr15 & 2137 & 684 & 11 & 0.43 & 4624 & 0.015 & 3.7 & 0.101 & 5.1 & 0.049 & 3.5 & 0.72 & 96 & 3.5 & 97 & 4.7 \\
\hline a33 & x, gr21 & 2841 & 461 & 14 & 0.98 & 10551 & 0.031 & 4.1 & 0.209 & 5.8 & 0.049 & 4.1 & 0.70 & 197.7 & 7.9 & 192.7 & 10.2 \\
\hline a34 & x, gr22 & 5072 & 845 & 25 & 1.46 & 13144 & 0.031 & 2.6 & 0.214 & 3.5 & 0.051 & 2.3 & 0.75 & 195 & 5.0 & 197 & 6 \\
\hline a35 & x, gr23 & 869 & 384 & 9 & 1.76 & 7537 & 0.017 & 2.4 & 0.125 & 5.7 & 0.052 & 5.2 & 0.42 & 111 & 2.7 & 119 & 6,5 \\
\hline
\end{tabular}

c: spot analysis on zircon core; x: spot analysis on xenocrystic zircon; r: spot analysis on outer overgrowth rim of zircon; gr: zircon grain number.

a marked west-east shift in the proximal-to-distal sedimentological facies- and the paleocurrent data, Varela (2009, 2011) suggests that such a change reflects the onset of the foreland stage at the Austral Basin. The lower section of the Mata
Amarilla Formation shows distal fluvial facies to the west, whereas to the east the deposits occur in a prograding sequence coarsening and thickening upwards from an estuary towards a bayhead delta. The middle section of the Mata Amarilla Formation 
shows, from west to east, a clear transition from gravel-bed braided systems to sandy high-sinuosity meandering fluvial systems; finally, in the eastern section the fluvial systems are of the anastomosing type (low-sinuosity meandring fluvial systems with aggradation). The upper section of the Mata Amarilla Formation shows a transition from distal fluvial deposits to the west -wherein the floodplain has been preserved to a great extent-to purely littoral facies to the east of the study area. The marked west-east change in the evolution of the fluvial systems, as well as the west-east transition from distal continental facies to estuarine facies, is coherent with the propagation direction of the Cretaceous fold-and-thrust belt of the Austral Basin. Therefore, the relative sea level changes of the Mata Amarilla Formation are related to tectonic control more than to purely eustatic fluctuations (Varela, 2009, 2011).

The onset of the foreland basin is regarded as coinciding clearly with the onset of deposition of the lower section of the Mata Amarilla Formation (Varela, 2009, 2011), as the increase in the rate of accommodation/sediment supply represents the flexural response of the lithosphere due to the increase in weight of the fold-and-thrust belt. Hence, according to this study, the age of compression is older than $96.2 \pm 0.7 \mathrm{Ma}$ and is located within the range between the lower Cenomanian and the upper Albian ( 100 Ma), since the Piedra Clavada Formation, underlying the Mata Amarilla Formation, is lower Albian (Fig. 7), as indicated by Mohria-like spores (Archangelsky, 2009).

The study area within this sector of the Austral Basin coincides with the edge of the Rocas Verdes Marginal Basin, which according to several contributions opened by 'unzipping' from south to north (de Wit and Stern, 1981; Biddle et al., 1986; Alabaster and Storey, 1990; Hervé et al., 2007a; Fildani and Hessler, 2005). Nevertheless, this 'unzipping' model was questioned by Calderón et al. (2007a) on the basis of new zircon ages. The Rocas Verdes Marginal Basin widens to the south and is narrower to the north, where the study area for this work is located (Fildani and Hessler, 2005; Romans et al., 2010, 2011). Therefore, when the basin is under compression-i.e., during the foreland stage-it is logical for the onset of the deformation to become more evident from north to south, as if the 'zipper' were closing. The depocentre of the basin is located in the Última Esperanza Province in Chile, to the southwest of the study area. In this region, the presence of the deep-marine sediments of the Punta Barrosa Formation over the shelf-marine sediments of the Zapata Formation indicates the occurrence of a well-developed subaerial fold-and-thrust belt (Wilson, 1991; Fildani et al., 2003; Fildani and Hessler, 2005; Romans et al., 2010; 2011; Fosdick et al., 2011). The Punta Barrosa Formation was dated on the basis of detrital zircon analysis, suggesting an age not older than $92 \pm 1 \mathrm{Ma}$ (Fildani et al., 2003). Fildani and Hessler (2005) suggest the occurrence of thrusting during the deposition of the Zapata-Punta Barrosa transition on the basis of provenance data. Recently, this incipient thrust belt formation was dated as being in progress at 101 Ma (Fosdick et al., 2011), but it has not caused significant changes in the sedimentary sequences (Fildani and Hessler, 2005; Romans et al., 2010). Yet, on the northern edge of the basin the crust is more rigid, as it is less thinned (Romans et al., 2010; Varela, 2011). That is why small uplifts in the arc and in the fold-and-thrust belt may have caused major changes in the sedimentary environments. In this regard, these uplifts have modified the general direction of the drainage network (northto-south), which in this case has shifted towards a marked west-to-east direction of flow.

In addition, the age obtained for the middle section of the Mata Amarilla Formation coincides with the peak age of the histogram for detrital zircons of the Punta Barrosa Formation, which is between 95 and $100 \mathrm{Ma}$ (see Fildani et al., 2003; Fig. 3B) and recently Fosdick et al. (2011) constrains the age of Punta Barrosa at 101 \pm 1 Ma (Fig. 7).

On the basis of the previously discussed data, it may be concluded that the compression and the ensuing development of the foreland basin occurred simultaneously throughout the basin (Fig. 8). In this sense, the onset of the compressional phase at $49.5^{\circ}$ south latitude in the lower section of the Mata Amarilla Formation must be older than 96.2 \pm 0.7 $\mathrm{Ma}$, whereas this compression becomes evident at $51.5^{\circ}$ south latitude in the Punta Barrosa Formation $\sim 100$ Ma (Fosdick et al., 2011; Fig. 8). These ages coincide with the beginning of the Andean uplift at the $34^{\circ}-35^{\circ} \mathrm{S}$ latitude (98.6 Ma-88 Ma) suggested by Tunik et al. (2010). However, Suárez et al. (2009a, 2009b, 2010 and references therein) argue 


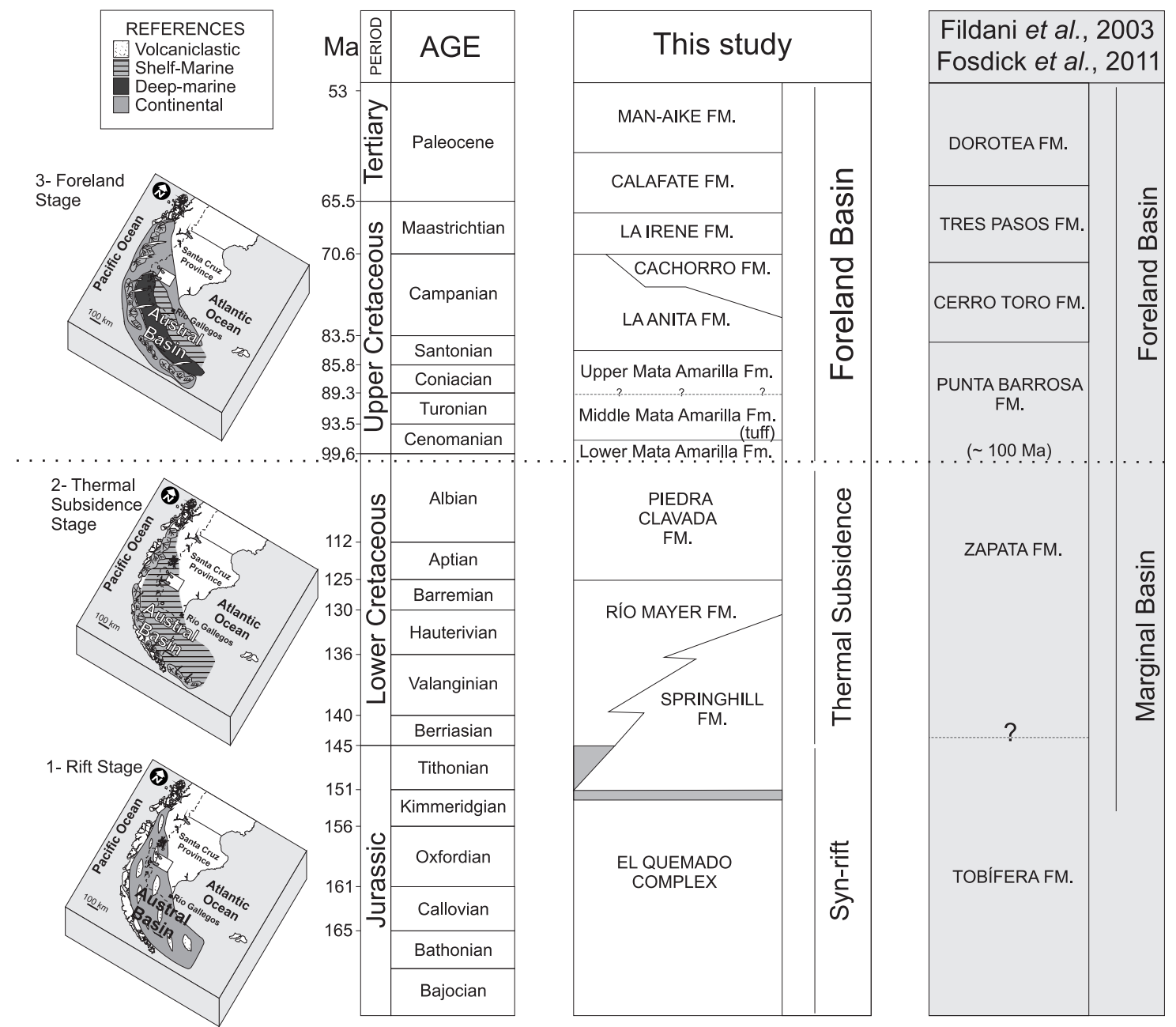

FIG. 8. Stratigraphic summary and geological history of the Austral Basin compared to the Rocas Verdes Marginal Basin-Magallanes Basin. Stratigraphy and data on the Rocas Verdes Marginal Basin-Magallanes Basin taken from Fildani et al. (2003) and Fosdick et al. (2011).

that the uplift of the Aisén Basin $\left(43^{\circ}-48^{\circ} \mathrm{S}\right.$ latitude), equivalent to the northern part of the Austral Basin, must have taken place some time between 121 and 118 Ma.

Finally, regarding the ages of the inherited zircon cores, an older group was found, which was located in the lower Permian (280-300 Ma, Fig. 7B); these ages are coherent with the age of the metamorphic rocks of the Austral Basin (see Hervé et al., 2003, 2010). In Argentina, it is known as the Bahía de la Lancha Formation and the Río Lácteo Formation; whereas in Chile it is represented in the metamorphic complexes of Aysén and Magallanes. These two were dated at the same latitude as the study area by Hervé et al. (2003, 2007b) and Augustsson et al. (2006).

In the graph of the inherited zircon cores (Fig. 7B), there is an absence of ages in the range between the lower Permian and the Jurassic, which could be related to the collision of the allochthonous Madre de Dios terrane (Thomson and Hervé, 2002). Likewise, Hervé et al. (2007a) pointed out the absence of plutonic rocks in the South Patagonian Batholith in the same time interval.

The second group of zircon cores with inherited ages lies between 180 and $200 \mathrm{Ma}$ (Lower Jurassic), which probably corresponds to another metamorphic event in the Chonos Metamorphic Complex and, 
less probably, in the Eastern Metamorphic Complex (Hervé et al., 2007a, b), or else to the Subcordilleran Batholith (Rapela et al., 2005). The youngest inherited age event is approximately $157 \mathrm{Ma}$ (Upper Jurassic), which is contemporary with the final stage of V3 volcanism (157-153 Ma) in Pankhurst et al. (2000). This extensive rhyolitic volcanism comprises the El Quemado Complex in Argentina and the Ibáñez and Tobífera Formations in Chile (Pankhurst et al., 2000; Suárez et al., 2009b). This magmatism is associated with a process of extensional continental rifting which caused the breakup of Gondwana (Pankhurst et al., 2000). On the other hand, the 157 to 145 Ma ages group could be more precisely related to a granitic magma emplacement in the South Patagonian Batholith (Hervé et al., 2007a). Therefore, Hervé et al. (2007a) assigned ages to the first constructional phase of the South Patagonian Batolith ranging from 157 to $145 \mathrm{Ma}$ (Late Jurassic), which is in part coeval with the rhyolitic ignimbrites of the Tobífera Formation (Pankhurst et al., 2000; Calderón et al., 2007a; Suárez et al., 2009b).

\section{Conclusion}

The time of deposition of the middle section of the Mata Amarilla Formation was U-Pb dated by means of zircons collected from a tuff layer at $96.2 \pm 0.7 \mathrm{Ma}$, which corresponds to the middle Cenomanian (Walker and Geissman, 2009). The onset of the foreland stage is considered to coincide clearly with the deposition of the lower section of the Mata Amarilla Formation (upper Albian-lower Cenomanian, 100 Ma).

Dating the middle section of the formation allowed us to suggest a more specific time frame for the Austral Basin (Fig. 8), as well as being of the utmost importance to understand the paleontological implications of the flora and fauna under study collected in the area.

The presence of Cenomanian deposits in continental facies is of considerable relevance as the Cenomanian is an extremely important period in the biological evolution of the Earth (Iglesias et al., 2007).

On the basis of this new data, it may be concluded that the compression and ensuing development of the Austral Foreland Basin occurred simultaneously, being the onset of compression older than $96.2 \pm 0.7$ Ma (upper Albian-lower Cenomanian, 100 Ma) at $49.5^{\circ}$ south latitude in the lower section of the Mata Amarilla Formation, which coincide with the compression at $51.5^{\circ}$ south latitude in the Punta Barrosa Formation 100 Ma (Fosdick et al., 2011).

\section{Acknowledgments}

This research was funded by the Consejo Nacional de Investigaciones Científicas y Técnicas (PIP 6237/05 and PIP 1016/10 awarded to D.G. Poiré), by the National Geographic Society (Grant 7901-05 awarded to T. Martin) and by the Deutsche Forschungsgemeinschaft (MA 1643/13-1). We would like to thank S. Richiano, J. Cuitiño, A. Zamuner, L. Chornogubsky, J. Schultz, J. O’Gorman, C. Koefoed and S. Iacobelli for their assistance in the field; to S. Jahn-Awe for her help when preparing the samples; to V. Ramos for his critical review of the manuscript; and to $\mathrm{M}$. Ponce for the translation of the first manuscript. We are indebted to Drs. Fildani, Hervé and Calderón for their generous advice and comments when reviewing the manuscript.

\section{References}

Ameghino, F. 1893. Sobre la presencia de vertebrados de aspecto mesozoico en la formación Santacruceña de la Patagonia austral. Revista del Jardín Zoológico de Buenos Aires 1: 76-84.

Ameghino, F. 1899. Nota preliminar sobre el Loncosaurus argentinus, un representante de la familia de los Megalosauridae en la República Argentina. Anales de la Sociedad Científica Argentina 47: 61-62.

Ameghino, F. 1906. Les formations sédimentaires du Crétacé Superieur et du Tertiaire de Patagonia, avec un paralèlle entre leurs faunes mammalogiques et celles de l'ancien continent. Anales del Museo Nacional de Buenos Aires 15: 1-568.

Alabaster, T.; Storey, B.C. 1990. Modified Gulf of California model for South Georgia, north scotia Ridge, and implications for the Rocas Verdes back-arc basin, southern Andes. Geology 18: 472-500.

Arbe, H.A. 1989. Estratigrafía, discontinuidades y evolución sedimentaria del Cretácico en la Cuenca Austral, Provincia de Santa Cruz. In Cuencas Sedimentarias Argentinas (Chebli, G.; Spalletti, L.A.; editors). Instituto Superior de Correlación Geológica, Universidad Nacional de Tucumán, Serie de Correlación Geológica 6: 419-442.

Arbe, H.A. 2002. Análisis estratigráfico del Cretácico de la Cuenca Austral. In Geología y Recursos Naturales de Santa Cruz (Haller, M.J.; editor). Congreso Geológico Argentino, No. 15. Relatorio: 103-128. El Calafate. 
Archangelsky, S. 2009. Biogeographic implications of Albian Mohria-like spores (Family Anemiaceae) in SW Gondwana (Patagonia). Review of Palaeobotany and Palynology 157: 301-308.

Augustsson, C.; Münker, C.; Bahlburg, H.; Fanning, M.C. 2006. Provenance of late Palaeozoic metasediments of the SW South American Gondwana margin: a combined U-Pb and Hf-isotope study of single detrital zircons. Journal of the Geological Society, 163: 983-995. London.

Berry, E.W. 1928. Tertiary fossil plants from the Argentine Republic. Proceedings of the United State National Museum, 73 (22): 1-27. Washington.

Biddle, K.; Uliana, M.; Mitchum, R. Jr.; Fitzgerald, M.; Wright, R. 1986. The stratigraphic and structural evolution of central and eastern Magallanes Basin, Southern America. In Foreland basins (Allen, P.; Homewood, P.; editors). International Association of Sedimentologists, Special Publication 8: 41-61.

Blasco, G.B.; Nullo, F.; Proserpio, C. 1980. SantonianoCampaniano: Estratigrafía y contenido amonitífero, Cuenca Austral. Revista Asociación Geológica Argentina 35 (4): 467-493.

Broin, F.; de la Fuente, M.S. 1993. Les tortues fossiles d'Argentine: Synthèse. Annales de Paléontologie 79: 169-232.

Calderón, M.; Fildani, A.; Hervé, F.; Fanning, C.M.; Weislogel, A.; Cordani, U. 2007a. Late Jurassic bimodal magmatism in the northern sea-floor remnant of the Rocas Verdes basin, southern Patagonian Andes. Journal of the Geological Society, 162: 1011-1022. London.

Calderón, M.; Hervé, F.; Massonne, H.-J.; Tassinari, C.G.; Pankhurst, R.J.; Godoy, E.; Theye, T. 2007b. Petrogenesis of the Puerto Edén Igneous and Metamorphic Complex, Magallanes, Chile: Late Jurrassic syn-deformational anatexis of metapelites and granitoid magma genesis. Lithos 93: 17-38.

Canessa, N.D.; Poiré, D.G.; Doyle, P. 2005. Estratigrafía de las unidades Cretácicas de la margen Norte del Lago Viedma, entre el Cerro Pirámides y la estancia Santa Margarita, provincia de Santa Cruz, República Argentina (Cabaleri, N.; Cingolani, C.A.; Linares, E.; López de Luchi, M.G.; Ostera, H.A.; Panarello, H.O.; editors). In Congreso Geológico Argentino, No. 16. Actas del CD-ROM Artículo 366: 8 p. La Plata.

Cione, A.L.; Gourie, S.; Goin, F.; Poiré, D. 2007. Atlantoceratodus, a new genus of lungfish from upper Cretaceous of South America and Africa. Revista del Museo de La Plata. Paleontología 10 (62): 1-12.
Dalziel, I.W.D. 1981. Back-arc extension in the southern Andes: A review and critical reappraisal. Royal Society of London Philosophical Transactions, serie A 300: 319-335.

Dalziel, I.W.D.; de Wit, M.J.; Palmer, K.F. 1974. Fossil marginal basin in the southern Andes. Nature 250: 291-294.

de la Fuente, M.S.; Lapparent de Broin, F.; Manera de Bianco, T. 2001. The oldest and first nearly complete skeleton of a chelid, of the Hydromedusa sub-group (Chelidae, Pleurodira), from the Upper Cretaceous of Patagonia. Bulletin de la Société Géologique de France 172: 237-244.

De Wit, M.J.; Stern, C.R. 1981. Variation in the degree of crustal extension during formation of a back-arc basin. Tectonophysics 72: 229-260.

Feruglio, E. 1936. Nota preliminar sobre algunas nuevas especies de moluscos del Supracretáceo y Terciario de la Patagonia. Notas del Museo de La Plata 1, Paleontología: 277-300.

Feruglio, E. 1937. Palontographia patagonica: Istituto Geologico della Università di Padova, Memorie 11: 1-384.

Feruglio, E. 1938. El Cretáceo superior del lago San Martín y de las regiones adyacentes. Physis 12: 293-342.

Fildani, A.; Cope, T.D.; Graham, S.A.; Wooden, J.L. 2003. Initiation of the Magallanes Foreland basin: Timing of the southermost Patagonian Andes orogeny revised by detrital zircon provenance analysis. Geology 31: 1081-1084.

Fildani, A.; Hessler, A.M. 2005. Stratigraphic record across a retroarc basin inversion: Rocas Verdes-Magallanes Basin, Patagonian Andes, Chile. Geological Society of America Bulletin 117: 1596-1614.

Folk, R.L.; Andrews, P.B.; Lewis, D.W. 1970. Detrital sedimentary rock classification and nomenclature for use in New Zealand. New Zealand Journal of Geology and Geophysics 13: 937-968.

Fosdick, J.C.; Romans, B.W.; Fildani, A.; Bernhardt, A.; Calderón, M.; Graham, S.A. 2011. Kinematic evolution of the Patagonian retroarc fold-and-thrust belt and Magallanes foreland basin, Chile and Argentina, $51^{\circ} 30^{\prime}$ S. Geological Society of America Bulletin 123: $1679-1698$

Fossa Mancini, E.; Feruglio, E.; Yussen de Campana, J.C. 1938. Una Reunión de geólogos de Y.P.F. y el problema de la Terminología Estratigráfica. Boletín de Informaciones Petroleras 171: 31-95.

Frei, D.; Gerdes, A. 2009. Accurate and precise in situ zircon U-Pb age dating with high spatial resolution and 
high sample throughput by automated LA-SF-ICP-MS. Chemical Geology 261 (3-4): 261-270.

Frenguelli, J. 1953. La flora Fósil de la región del alto Río Chalía en Santa Cruz (Patagonia). Notas Museo de La Plata, No. 16, Paleontología 98: 239-257.

Gerdes, A.; Zeh, A. 2006. Combined U-Pb and Hf isotope LA-(MC-) ICP-MS analyses of detrital zircons: Comparison with SHRIMP and new constraints for the provenance and age of an Armorican metasediment in Central Germany. Earth and Planetary Science letters 249: 47-62.

Gerdes, A.; Zeh, A. 2009. Zircon formation versus zircon alteration-New insights from combined $\mathrm{U}-\mathrm{Pb}$ and Lu-Hf in situ La-ICP-MS analyses of Archean zircons from the Limpopo Belt. Chemical Geology 261 (3-4): 230-243.

Goin, F.J.; Poiré, D.G.; De La Fuente, M.S.; Cione, A.L.; Novas, F.E.; Bellosi, E.S.; Ambrosio, A.; Ferrer, O.; Canessa, N.D.; Carloni, A.; Ferigolo, J.; Ribeiro, A.M.; Sales Viana, M.S.; Pascual, R.; Reguero, M.; Vucetich, M.G.; Marenssi, S.; De Lima Filho, M.; Agostinho, S. 2002. Paleontología y Geología de los sedimentos del Cretácico Superior aflorantes al sur del Río Shehuen (Mata Amarilla, Provincia de Santa Cruz, Argentina). In Congreso Geológico Argentino, No. 15, Actas: 603-608. El Calafate.

Griffin, M.; Varela, A.N. 2012. Mollusk fauna from the Mata Amarilla Formation (lower Upper Cretaceous), southern Patagonia Argentina. Cretaceous Research 37: 164-176.

Hervé, F.; Fanning, C.M., Pankhurst, R.J. 2003. Detrital Zircon Age Patterns and Provenance in the metamorphic complexes of Southern Chile. Journal of South American Earth Sciences 16: 107-123.

Hervé, F.; Pankhurst, R.J.; Fanning, C.M.; Calderón, M.; Yaxley, G.M. 2007a. The South Patagonian batholith: 150 my of granite magmatism on a plate margin. Lithos 97: 373-394.

Hervé, F.; Faúndez, V.; Calderón, M.; Massonne, H.-J.; Willner, A.P. 2007b. Metamorphic and plutonic basament complexes. In The Geology of Chile (Moreno, T.; Gibbons, W.; editors). The Geological Society of London: 5-20. London.

Hervé, F.; Calderón, M.; Fanning, C.M.; Kraus, S.; Pankhurst, R.J. 2010. SHRIMP chronology of the Magallanes Basin basement, Tierra del Fuego: Cambrian plutonism and Permian high-grade metamorphism. Andean Geology 37 (2): 253-275.

Iglesias, A.; Zamuner, A.B.; Poiré, D.G.; Larriestra, F. 2007. Diversity, taphonomy and palaeoecology of an angiosperms flora from Cretaceous (CenomanianConiacian) in Southern Patagonia, Argentina. Palaeontology 50: 445-466.

Iglesias, A.; Zamuner, A.B.; Poiré, D.G.; Varela, A.N.; Richiano, S.; Koefoed, C. 2009. Albian-Campanian continous record of compression floras in Tres Lagos, Austral Basin, Patagonia, Argentina. In Reunión Anual de Comunicaciones de la Asociación Paleontológica Argentina. Actas (abstracts): 51-52. Buenos Aires.

Ihering, H. Von. 1907. Les mollusques fossiles du Tertiare et du Crétacé superieur de l'Argentine. Anales Museo Nacional de Buenos Aires (3) 7: 1-611.

Katz, H.R. 1963. Revision of Cretaceous stratigraphy in Patagonian cordillera of Última Esperanza, Magallanes Province, Chile. American Association of Petroleum Geologists Bulletin 47: 506-524.

Kraemer, P.E.; Riccardi, A.C. 1997. Estratigrafía de la región comprendida entre los lagos Argentino y Viedma (4940’ $-50^{\circ} 10^{\prime}$ latitud S), provincia de Santa Cruz. Revista de la Asociación Geológica Argentina 52 (3): 333-360.

Kraemer, P.; Ploszkiewicz, J.V.; Ramos, V.A. 2002. Estructura de la Cordillera Patagónica Austral entre los $40^{\circ}$ y $52^{\circ} \mathrm{S}$. In Geología y Recursos Naturales de Santa Cruz (Haller, M.J.; editor). In Congreso Geológico Argentino, No. 15. Relatorio: 353-364. El Calafate.

Lacovara, K.; Harris, J.; Lammana, M.; Novas, F.; Martínez, R.; Ambrosio, A. 2004. An enormous sauropod from the Maastritchtian Pari Aike Formation of southernmost Patagonia. Journal of Vertebrate Paleontology, Suppl. 24: 81A.

Lapparent de Broin, F.; de la Fuente, M.S. 2001. Oldest world Chelidae (Chelonii, Pleurodira) from the Cretaceous of Patagonia. Comptes Rendus de l'Académie des Sciences-Series IIA-Earth and Planetary Science 333 (8): 463-470.

Leanza, A.F. 1970. Amonites nuevos o poco conocidos del Aptiano, Albiano y Cenomaniano de los Andes Australes con notas acerca de su posición estratigráfica. Revista de la Asociación Geológica Argentina 25 (2): 197-261.

Leanza, A.F. 1972. Andes Patagónicos Australes. In Geología Regional Argentina (Leanza, A.F.; editor). Academia Nacional de Ciencias: 689-706. Córdoba.

Ludwig, K.R. 2003. User's manual for Isoplot/Ex-Version 3.0, A geochronological toolkit for Microsoft Excel. Berkeley Geochronology Centre, Special Publication 4: 2455 p.

Novas, F.E.; Martínez, R.; De Valais, S.; Ambrosio, A. 1999. Nuevos registros de Carcharodontosauridae 
(Dinosauria, Theropoda) en el Cretácico de Patagonia. Ameghiniana Suppl. 36 (4): p. 17.

Novas, F.E.; Bellosi, E.S.; Ambrosio, A. 2002. Los 'Estratos con Dinosaurios’ del Lago Viedma y Río Leona (Santa Cruz): sedimentología y contenido fosilífero. In Congreso Geológico Argentino, No. 15. Actas: 596-602. El Calafate.

Novas, F.E.; Cambiaso, A.V.; Ambrosio, A. 2004a. A new basal iguanodontian (Dinosauria, Ornithischia) from the Upper Cretaceous of Patagonia. Ameghiniana 41: 75-82.

Novas, F.E.; Lecuona, A.; Calvo, J.; Porfiri, J. 2004b. Un terópodo del Cretácico Superior de la provincia de Santa Cruz. Ameghiniana 41 (4): 59R.

Novas, F.E.; Salgado, L.; Calvo, J.; Agnolín, F. 2005. Giant Titanosaur (Dinosauria, Sauropoda) from the late Cretaceous of Patagonia. Revista del Museo Argentino de Ciencias Naturales 7 (1): 37-41.

Novas, F.E.; Ezcurra, M.A.; Lecuona, A. 2008. Orkoraptor burkei nov. gen. et sp., a large theropod from the Maastrichtian Pari Aike formation, Southern Patagonia, Argentina. Cretaceous Research 29: 468-480.

Nullo, F.E.; Proserpio, C.A.; Blasco de Nullo, G. 1981. El Cretácico de la Cuenca Austral entre el Lago San Martín y Río Turbio. In Cuencas Sedimentarias del Jurásico y Cretácico de América del Sur (Volkheimer, W.; Mussachio, E.A; editors): 181-220. Buenos Aires.

O’Gorman, J.P.; Varela, A.N. 2010. The oldest lower Upper Cretaceous plesiosaurs (Reptilia, Sauropterygia) from the southern Patagonia, Argentina. Ameghiniana 47 (4): 447-459.

Pankhurst, R.J.; Riley, T.R.; Fanning, C.M.; Kelley, S.P. 2000. Episodic silicic Volcanism in Patagonia and Antarctic Peninsula: Chronology of magmatism associated with the break-up of Gondwana. Journal of Petrology 41: 605-625.

Peroni, G.; Cagnolatti, M.; Pedrazzini, M. 2002 Cuenca Austral: marco geológico y reserva histórica de la actividad petrolera. In Simposio Rocas Reservorio de las Cuencas Productivas de la Argentina. (Schiuma, M.; Hinterwimmer, G.; Vergani, G.; editors). Congreso de Exploración y Desarrollo de Hidrocarburos, No. 5: 11-19. Mar del Plata.

Piatnitzky, A. 1938. Observaciones Geológicas en el Oeste de Santa Cruz (Patagonia). Boletín de Informaciones Petroleras 165: 45-85.

Poiré, D.G.; Zamuner, A.B.; Goin, F.; Iglesias, A.; Canessa, N.; Larriestra, C.N.; Varela, A.N.; Calvo Marcillese, L.; Larriestra, F. 2004. Ambientes sedimentarios relacionados a las tafofloras de las formaciones Piedra Clavada y
Mata Amarilla (Cretácico), Tres Lagos, Cuenca Austral, Argentina. In Reunión Argentina de Sedimentología, No. 10, Actas (abstracts): 140-141. San Luis.

Ramos, V.A. 1989. Andean Foothills structures in northern Magallanes Basin, Argentina. American Association of Petroleum Geologists Bulletin 73: 887-903.

Ramos, V.A. 2002. Evolución Tectónica. In Geología y Recursos Naturales de Santa Cruz (Haller, M.J.; editor). Congreso Geológico Argentino, No. 15, Relatorio: 365-390. El Calafate.

Ramos, V.A.; Niemeyer, H.; Skarmeta, J.; Muñoz, J. 1982. Magmatic evolution of the austral patagonian Andes. Earth-Science Reviews 18: 411-443.

Rapela, C.W.; Pankhurst, R.J.; Fanning, C.M.; Hervé, F. 2005. Pacific subduction coeval with the Karoo mantle plume: the Early Jurassic Subcordilleran belt of northwestern Patagonia. In Terrane Processes at the Margins of Gondwana (Vaughan, A.P.M.; Leat, P.T.; Pankhurst, R.J.; editors). Geological Society, London, Special Publication 246: 217-240.

Riccardi, A.C. 1984a. Las Asociaciones de Amonitas del Jurásico y Cretácico de la Argentina. In Congreso Geológico Argentino, No. 9, Actas 4: 559-595. Buenos Aires.

Riccardi, A.C. 1984b. Las Zonas de Amonitas del Cretácico de la Patagonia (Argentina y Chile). In Congreso Latinoamericano de Paleontología, No. 3. Memoria: 394-405.

Riccardi, A.C. 2002. Invertebrados del Cretácico Superior. In Geología y Recursos Naturales de Santa Cruz (Haller, M.J.; editor). Congreso Geológico Argentino, No. 15, Relatorio: 461-479. El Calafate.

Riccardi, A.C.; Rolleri, E.O. 1980. Cordillera Patagónica Austral. In Simposio de Geología Regional Argentina, No. 2 (Turner, J.C.; editor). Academia Nacional de Ciencias de Córdoba 2: 1163-1306. Córdoba.

Riccardi, A.C.; Aguirre Urreta, M.B.; Medina, F. 1987. Aconeceratidae (Ammonitina) from the HauterivianAlbian of southern Patagonia. Palaeontographica 196: 105-185.

Robbiano, J.A.; Arbe, H.; Bangui, A. 1996. Cuenca Austral Marina. In Geología y Recursos Naturales de la Plataforma continental Argentina (Ramos, V.A.; Turic, M.; editors). Congreso Geológico Argentino, No. 13, Relatorio, y Congreso de Exploración de Hidrocarburos, No. 3: 343-358. Buenos Aires.

Rodríguez, J.F.; Miller, M. 2005. Cuenca Austral. In Frontera Exploratoria de la Argentina (Chebli G. et al.; editors). In Congreso de Exploración y Desarrollo de Hidrocarburos, No. 6: 308-323. Mar del Plata. 
Romans, B.W.; Fildani, A.; Graham, S.A.; Hubbard, S.M.; Covault, J.A. 2010. Importance of the predecessor basin history on the sedimentary fill of a retroarc foreland basin: provenance analysis of the Cretaceous Magallanes basin, Chile (50-52S). Basin Research 22: 648-658.

Romans, B.W.; Fildani, A.; Hubbard, S.M.; Covault, J.A.; Fosdick, J.C.; Graham, S.A. 2011. Evolution of deepwater stratigraphic architecture, Magallanes Basin, Chile. Marine and Petroleum Geology 28: 612-628.

Russo, A.; Flores, M.A. 1972. Patagonia Austral Extraandina. In Geología Regional Argentina (Leanza, A.F.; editor). Academia Nacional de Ciencias: 707-725. Córdoba.

Russo, A.; Flores, M.A.; Di Benedetto, H. 1980. Patagonia Austral Extraandina (Turner, J.C.M.; editor). In Simposio de Geología Regional Argentina, No. 2. Academia Nacional de Ciencias de Córdoba 2: 1431-1462. Córdoba.

Spalletti, L.A.; Franzese, J.R. 2007. Mesozoic Paleogeography and Paleoenvironmental evolution of Patagonia (Southern South America). In Patagonian Mesozoic Reptiles (Gasparini, Z.; Salgado, L.; Coria, R.A.; editors). Indiana University Press, Bloomington \& Indianapolis: 29-49. Indianapolis.

Suárez, M.; De la Cruz, R.; Bell, M.; Demant, A. 2009a. Cretaceous slab segmentation in Southwestern Gondwana. Geological Magazine 147 (1): 1-13.

Suárez, M.; De la Cruz, R.; Aguirre-Urreta, B.; Fanning, M. 2009b. Relationship between volcanism and marine sedimentation in northern Austral (Aisén) Basin, central Patagonia: Stratigraphic, U-Pb SHRIMP and paleontologic evidence. Journal of South American Earth Sciences 27: 309-325.

Suárez, M.; Demant, A.; De la Cruz, R.; Fanning, C.M. 2010. ${ }^{40} \mathrm{Ar} /{ }^{39} \mathrm{Ar}$ and U-Pb SHRIMP dating of Aptian tuff cones in the Aisén Basin, Central Patagonian Cordillera. Journal of South American earth Sciences 29: 731-737.

Thomson, S.T.; Hervé, F. 2002. New time constraints for the age of metamorphism at the ancestral Pacific Gondwana margin of southern Chile (42-52 $\mathrm{S})$. Revista Geológica de Chile 29 (2): 152-165.

Tunik, M.; Folguera, A.; Naipauer, M.; Piementel, M.; Ramos, V.A. 2010. Early uplift and orogenic deformation in the Neuquén Basin: Constraints on the Andean uplift from $\mathrm{U}-\mathrm{Pb}$ and $\mathrm{Hf}$ isotopic data of detrital zircons. Tectonophysics 489: 258-273.

Uliana, M.A.; Biddle, K.T. 1988. Mesozoic-Cenozoic paleogeographic and geodynamic evolution of southern South America. Revista Brasileira de Geociências 18: 172-190.
Varela, A.N.; Poiré, D.G. 2008. Paleogeografía de la Formación Mata Amarilla, Cuenca Austral, Patagonia, Argentina. In Reunión Argentina de Sedimentología, No. 12. Actas (abstracts): p.183. Buenos Aires.

Varela, A.N.; Richiano, S.; Poiré, D.G. 2008. Análisis paleoambiental de la Formación Mata Amarilla a partir de su malacofauna, Cuenca Austral, Patagonia, Argentina. In Trabajos Técnicos (Schiuma, M.; editor). Congreso de Exploración y Desarrollo de Hidrocarburos, No. 12: 601-605. Mar del Plata.

Varela, A.N. 2009. Accommodation/sediment supply fluvial deposition controlled by base level changes and relative sea level fluctuations in the Mata Amarilla Formation (Early Upper Cretaceous), Southern Patagonia, Argentina. In International Conference on Fluvial Sedimentology, No. 9. Acta Geológica Lilloana 21: p. 66. San Miguel de Tucumán.

Varela, A.N. 2010. Paleosol development in response to extrinsic and intrinsic factors: The Mata Amarilla Formation (lower Upper Cretaceous), an example of southern Patagonia (Schwarz, E.; Georgieff, S.; Piovano, E.; Ariztegui, D.; editors). In International Sedimentological Congress, No. 18: p. 892. Mendoza.

Varela, A.N. 2011. Sedimentología y Modelos Deposicionales de la Formación Mata Amarilla, Cretácico de la Cuenca Austral, Argentina. Ph.D. Thesis (Unpublished), Universidad Nacional de La Plata, Facultad de Ciencias Naturales y Museo: 287 p.

Walker, J.D.; Geissman, J.W. 2009. Geologic Time Scale. Geological Society of America, CTS004R2C, Boulder, Colorado.

Wilckens, O. 1907. Die Lamellibranchiaten, Gastropoden etc, der oberen Kreide Südpatagoniens. Berichte der Naturforschenden Gesellschaft zu Freiburg 15: 1-70.

Wilson, T.J. 1991. Transition from back-arc to foreland basin development in southernmost Andes: Stratigraphic record from the Última Esperanza District, Chile. Geological Society of America Bulletin 103: 98-111.

Zamuner, A.B.; Poiré, D.G.; Iglesias, A.; Larriestra, F.; Varela, A.N. 2004. Upper Cretaceous in situ Petrified Forest In Mata Amarilla Formation, Tres Lagos, Southern Patagonia, Argentina. International Organization of Paleobotany Conference, No. 7, Actas (abstracts): p. 150. Bariloche.

Zamuner, A.; Falaschi, P.; Bamford, M.; Iglesias, A.; Poiré, D.G.; Varela, A.N.; Larriestra, F. 2006. Anatomía y Paleocología de dos Bosques in situ de la Zona de Tres Lagos, Formación Mata Amarilla, Cretácico superior, Patagonia, Argentina. In Simposio Argentino de Pa- 
leobotánica y Palinología, No. 13, Actas (abstracts): p. 55. Bahía Blanca.

Zamuner, A.B.; Poiré, D.G.; Iglesias, A.; Koefoed, C.; Varela, A.N. 2008. Albian-Cenomanian Floral Chan- ges in southern Patagonia, Argentina. In International Palynological Congress, No. 12, and International Organisation of Palaeobotany Conference, No. 8, Actas (abstracts): 315-316. Bonn, Germany.

Manuscript received: March 2, 2011; revised/accepted: October 28, 2011; available online: June 19, 2012. 